\title{
Birch leaves and branches as a source of ice-nucleating macromolecules
}

\author{
Laura Felgitsch $^{1}$, Philipp Baloh ${ }^{1}$, Julia Burkart ${ }^{1}$, Maximilian Mayr ${ }^{1}$, Mohammad E. Momken ${ }^{1}$, Teresa M. Seifried ${ }^{1}$, \\ Philipp Winkler ${ }^{1}$, David G. Schmale III $^{2}$, and Hinrich Grothe ${ }^{1}$ \\ ${ }^{1}$ Institute of Materials Chemistry, TU Wien, Vienna, 1060, Austria \\ ${ }^{2}$ School of Plant and Environmental Sciences, Virginia Tech, 24061-0390 Blacksburg, Virginia, USA
}

Correspondence: Hinrich Grothe (hinrich.grothe@tuwien.ac.at)

Received: 6 November 2017 - Discussion started: 15 November 2017

Revised: 7 September 2018 - Accepted: 1 October 2018 - Published: 8 November 2018

\begin{abstract}
Birch pollen are known to release ice-nucleating macromolecules (INM), but little is known about the production and release of INM from other parts of the tree. We examined the ice nucleation activity of samples from 10 different birch trees (Betula spp.). Samples were taken from nine birch trees in Tyrol, Austria, and from one tree in a small urban park in Vienna, Austria. Filtered aqueous extracts of 30 samples of leaves, primary wood (new branch wood, green in colour, photosynthetically active), and secondary wood (older branch wood, brown in colour, with no photosynthetic activity) were analysed in terms of ice nucleation activity using VODCA (Vienna Optical Droplet Crystallization Analyser), a cryo microscope for emulsion samples. All samples contained ice-nucleating particles in the submicron size range. Concentrations of ice nuclei ranged from $6.7 \times 10^{4}$ to $6.1 \times 10^{9} \mathrm{mg}^{-1}$ sample. Mean freezing temperatures varied between -15.6 and $-31.3{ }^{\circ} \mathrm{C}$; the range of temperatures where washes of birch pollen and dilutions thereof typically freeze. The freezing behaviour of three concentrations of birch pollen washing water (initial wash, $1: 100$, and $1: 10000$ ) were significantly associated with more than a quarter of our samples, including some of the samples with highest and lowest activity. This indicates a relationship between the INM of wood, leaves, and pollen. Extracts derived from secondary wood showed the highest concentrations of INM and the highest freezing temperatures. Extracts from the leaves exhibited the highest variation in INM and freezing temperatures. Infrared spectra of the extracts and tested birch samples show qualitative similarity, suggesting the chemical components may be broadly similar.
\end{abstract}

\section{Introduction}

Pure water can typically be supercooled to temperatures below the melting point of ice $\left(0^{\circ} \mathrm{C}\right.$ at atmospheric pressure $)$ without freezing (Cantrell and Heymsfield, 2005; Hegg and Baker, 2009; Murray et al., 2010). In order to freeze, water molecules have to be arranged in an ice-like pattern and overcome a critical cluster size (Turnball and Fisher, 1949; Cantrell and Heymsfield, 2005). This freezing mechanism, if happening as a stochastic process from the pure liquid, and in the absence of catalysing substances, is called homogeneous ice nucleation (Cantrell and Heymsfield, 2005). In micrometre-sized droplets, this phase change takes place at temperatures below $-35^{\circ} \mathrm{C}$ (Pruppbacher and Klett, 1997). However, freezing can also be triggered at higher sub-zero temperatures by foreign substances (Dorsey, 1948) called ice-nucleating particles (INP, Vali et al., 2015), which is referred to as heterogeneous freezing. In the atmosphere, INP can contribute to cloud glaciation and precipitation (Lohmann, 2002). Ice clouds impact the radiation balance of the Earth and therefore our climate (Mishchenko et al., 1996; Baker, 1997; Lohmann, 2002; Forster et al., 2007). Representatives of many different substance classes of aerosols have been found to act as INP (Hoose and Möhler, 2012; Murray et al., 2012). Despite this ubiquitous distribution throughout different aerosol species, ice nucleation active material only represents a small part of total atmospheric aerosol (Rogers et al., 1998). Typical total aerosol concentrations range between $10^{2}$ and $10^{3} \mathrm{~cm}^{-3}$ for free troposphere and marine boundary layer concentrations, and between $10^{3}$ and $10^{5} \mathrm{~cm}^{-3}$ for continental boundary layer concentrations (Spracklen et al., 2010). INP concentrations are much lower 
and range between $10^{-1}$ and $10^{-4} \mathrm{~cm}^{-3}$ (Rogers et al., 1998; DeMott et al., 2010).

There are significant gaps in the understanding of heterogeneous ice nucleation and the contributions of different sources of INP. The role of biological substances in this process is understudied (Möhler et al., 2007; Murray et al., 2012). Field studies have demonstrated that the biosphere acts as an important source of primary aerosol particles (Jaenicke, 2005). Jia et al. (2010) analysed carbon sources of $\mathrm{PM}_{2.5}$ particles (particulate matter with an aerodynamic diameter of $2.5 \mu \mathrm{m}$ or smaller) collected at an urban site and a rural site in Texas, and attributed 5\%-13\% of the particle mass to primary biological sources and $4 \%-9 \%$ to secondary organic aerosols. Biological residues can be adsorbed on dust particles (O'Sullivan et al., 2016). Even small amounts of adsorbed biological matter can increase nucleation temperatures of less active INP (Conen et al., 2011). Several studies point to the importance of biological material in cloud processes. Precipitation can contain large amounts of INP. Petters and Wright (2015) combined data from a large number of measurements and found a high variability in concentration in the range between -5 and $-12^{\circ} \mathrm{C}$, which is assumed to be biological, with a maximum of approx. $500000 \mathrm{INPL}^{-1}$ water. Christner et al. (2008) analysed snow and rain samples from the United States (Montana and Louisiana), the Alps and the Pyrenees, Antarctica (Ross Island), and Canada (Yukon), where they found rather low INP concentrations, with biological INP representing the majority of the INP. Pratt et al. (2009) examined ice crystal residues collected from ice clouds $8 \mathrm{~km}$ over Wyoming, US, and about a third of the collected material was of biological origin. Moreover, $60 \%$ of the highly abundant mineral dusts were internally mixed with biological or humic substances. Kamphus et al. (2010) analysed ice crystal residues from mixed phase clouds at the Jungfraujoch station in the Swiss Alps, and found that $2 \%-3 \%$ of the material at $3500 \mathrm{~m}$ could be classified as biological. Conen et al. (2016) found indications that leaf litter, which naturally hosts a vast variety of microorganisms, enriches Arctic air with ice-nucleating particles. Huffman et al. (2013) collected aerosols above woodlands in Colorado. They observed a burst in biological INP concentrations in the atmosphere that appeared to be linked to rain events. Since biological INP are capable of influencing cloud glaciation and precipitation (Sands et al., 1982; Morris et al., 2014), rain-induced bursts might be important contributors to atmospheric and hydrological processes.

Biological material from plants could be an abundant source of INP. The controlled freezing of water within a plant is an important mechanism for plants to cope with cold climatic conditions. The freezing of water is challenging for living organisms, since it often leads to lethal injuries during the process (Storey and Storey, 2004). Some plants that are exposed to cold stress have developed unique strategies to ensure their survival (Zachariassen and Kristiansen, 2000). Intracellular freezing can lead to a disruption of the cell and typically has lethal consequences for the cell and subsequently for the plants (Mazur, 1969; Burke et al., 1976; Pearce, 2001). Many plants grow in climatic zones where temperatures regularly fall low enough to make a complete avoidance of freezing impossible. To avoid cell damage under such conditions, those plants typically trigger the freezing process in their extracellular spaces (Burke et al., 1976), a process that can be achieved by releasing INP in the plant's tissue. This freezing process leads to a dehydration of the cell, due to the attraction of intracellular water by extracellular ice (Mazur, 1969). Dehydration induces several changes inside of cells such as changes in $\mathrm{pH}$, salt concentration, and protein denaturation. Therefore, frost hardiness is often defined by the degree of dehydration a plant can survive (Burke et al., 1976). During cell dehydration, a rapid increase in concentration of ions and small molecules inside the cell takes place, leading to freezing point depression and thus hindering intracellular ice formation (Burke et al., 1976). If temperatures fall too low, the high intracellular salt concentration often promotes glass formation (Hirsh et al., 1985). Frost hardy plants are able to survive rapid cooling to liquid nitrogen temperatures, if they are pre-frozen at -15 to $-30^{\circ} \mathrm{C}$ depending on the plant and time of the year (Sakai, 1973). These results show that controlled freezing can be an important mechanism for plants to cope with cold climatic conditions. Though even controlled freezing comes with a risk for plants (e.g. cavitation due to bubble formation, Sperry and Sullivan, 1992), many plants have been found to be ice nucleation active. Such plants include blueberry (Kishimoto et al., 2014), sea buckthorn (Jann et al., 1997; Lundheim and Wahlberg, 1998), and winter rye (Brush et al., 1994). These processes and findings indicate that plants are a viable source of INP, a topic that requires further study.

Spectroscopic methods are a key instrument in characterizing complex biological systems. One of the methods typically applied to biological materials is infrared spectroscopy (Baker et al., 2015), which allows characterization and discrimination of plants (Kim et al., 2004; Gorgulu et al., 2007; Anilkumar et al., 2012; Carballo-Meilan et al., 2014). Further, infrared spectroscopy has already been shown to respond well to the biochemical features of pollen of different species (Gottardini et al., 2007; Pummer et al., 2013; Zimmermann and Kohler, 2014; Bağcioğu et al., 2015). It can even be used to gain information on the environmental conditions (Zimmermann and Kohler, 2014).

In our study, we examined INP of different parts of birch trees. Birch pollen are already known to exhibit ice nucleation activity (INA) (Diehl et al., 2001), and recent research suggests that pollen grains play a role in local INP concentrations during peak pollen periods (Kohn, 2016). They easily release their ice nucleation active compounds which are in the macromolecular size range (Pummer et al., 2012). However, little is known about the production and release of these ice-nucleating macromolecules (INM) from other parts of the tree. We hypothesized that the materials throughout 
Table 1. Further information on the sampled birches, with sample name, GPS waypoints, altitude of the growing site, circumference, and description of the growing site.

\begin{tabular}{|c|c|c|c|c|}
\hline $\begin{array}{l}\text { ID of } \\
\text { birch tree }\end{array}$ & GPS waypoints & $\begin{array}{r}\text { GPS } \\
\text { altitude }\end{array}$ & $\begin{array}{r}\text { Circumference at } \\
1 \mathrm{~m} \text { height }\end{array}$ & Location description \\
\hline TBA & $47.214241,10.798765$ & $799 \mathrm{~m}$ & $113 \mathrm{~cm}$ & Roadside birch in the valley \\
\hline TBB & $47.221615,10.829835$ & $799 \mathrm{~m}$ & $54 \mathrm{~cm}$ & Roadside birch in the valley \\
\hline TBC & $47.186231,10.908341$ & $851 \mathrm{~m}$ & $75 \mathrm{~cm}$ & Riverside birch in the valley \\
\hline TBD & $47.185387,10.909587$ & $851 \mathrm{~m}$ & $35 \mathrm{~cm}$ & Riverside birch in the valley \\
\hline TBE & $46.973163,11.010921$ & $1343 \mathrm{~m}$ & $96 \mathrm{~cm}$ & Riverside birch in Sölden next to a road with little traffic \\
\hline TBF & $46.974588,11.011463$ & $1343 \mathrm{~m}$ & $61 \mathrm{~cm}$ & Riverside birch in Sölden next to a road with little traffic \\
\hline TBG & $46.878959,11.024441$ & $1925 \mathrm{~m}$ & $67 \mathrm{~cm}$ & $\begin{array}{l}\text { Timberline birch, the last birch and one of the last trees in } \\
\text { general we encountered on our way up }\end{array}$ \\
\hline TBH & $46.873275,11.026616$ & $1883 \mathrm{~m}$ & $36 \mathrm{~cm}$ & Riverside birch in Obergurgl close to the timberline \\
\hline TBI & $46.873279,11.026736$ & $1883 \mathrm{~m}$ & $59 \mathrm{~cm}$ & Riverside birch in Obergurgl close to the timberline \\
\hline VB & $48.197796,16.352189$ & $195 \mathrm{~m}$ & $86 \mathrm{~cm}$ & $\begin{array}{l}\text { Located in the centre of a small park in Vienna, } \\
\text { which is surrounded by heavy traffic }\end{array}$ \\
\hline
\end{tabular}

birch trees are ice nucleation active and that the active compound(s) in these birch materials from different parts of the tree are similar to those in birch pollen. The specific objectives of this study were to (1) investigate the INA of the different birch tree samples, especially in regard to similarities to the INM, which have already been found in birch pollen (Pummer et al., 2012, 2015), (2) determine the distribution of INM throughout leaves and branches of birch trees, and (3) compare spectroscopic and ice nucleation results of different birch trees to establish the variability in the chemical nature and INA of the different trees.

\section{Materials and methods}

\subsection{Samples}

Samples were collected from nine birches in Tyrol, Austria (named TB for Tyrolian Birch and numbered A to I), and one birch located in an urban park in Vienna, Austria, in the spring and summer of 2016. Detailed descriptions of all investigated birches can be found in Table 1. Larger branches were removed from the lower $3 \mathrm{~m}$ of the canopy, and were divided into three sample groups including leaves, $\sim 5 \mathrm{~cm}$ sections of primary wood (green, photosynthetically active), and $\sim 5 \mathrm{~cm}$ sections of secondary wood (brown, no photosynthetic activity). Representative material was combined for each tree, resulting in 30 bulk samples ( 1 bulk sample of each category, per tree) for downstream analyses. All tools used were surface disinfected with $90 \%$ ethanol prior to branch removal. The samples were stored in a cooler for transport back to the laboratory, and were frozen within a few hours of collection at $-20^{\circ} \mathrm{C}$. The Tyrolian samples were collected along an altitudinal gradient (from altitudes between 799 and $1925 \mathrm{~m}$ ). The locations of the Tyrolian birches are shown in Fig. 1. Birch pollen used for FTIR spectroscopy was Betula pendula pollen from AllergonAB (Thermo Fisher).

\subsection{Sample preparation}

Samples were processed using the following milling procedure. Prior to milling, visible contaminations on the outside of the samples (e.g. lichens) were removed. A swing mill (Retsch MM400) was used (with a frequency of $25 \mathrm{~s}^{-1}$ ) to mill each of the samples. We used approx. $20 \mathrm{~cm}$ increments per wood sample (cut into pieces of about $0.5 \mathrm{~cm}$ ) and two to three leaves per leaf sample, which were milled and bulked together. In all cases the wood and leaf samples stemmed from a single branch per tree. Each sample was cooled with liquid nitrogen between two milling steps. This was achieved by immersing the milling container containing the sample and the ball (stainless steel) in liquid nitrogen. After equilibrium was reached, we remounted the container on the mill and conducted the next milling step. We milled each sample four times for $30 \mathrm{~s}$. After the milling process, the products were dried in vacuum over silica gel until the weight was constant. All samples were dried for at least $12 \mathrm{~h}$. Weight consistency was determined by two weighing steps separated by at least $2 \mathrm{~h}$ of drying. Total dry mass of the sample bulks varied between approx. 100 and $600 \mathrm{mg}$. Part of the dried bulk was immersed in ultrapure water (produced with Millipore ${ }^{\circledR}$ SAS SIMSV0001) (1 mL per $50 \mathrm{mg}$ of powder). Over a time of $6 \mathrm{~h}$ the mixture was shaken two to four times. Afterwards it was centrifuged ( $3500 \mathrm{rpm} / 1123 \mathrm{xg}$ for $5 \mathrm{~min}$ ) and the supernatant was pressed through a $0.2 \mu \mathrm{m}$ syringe filter (VWR, cellulose acetate membrane, sterile), removing all bigger particles, as well as possible impurities, e.g. intact bacterial cells.

Birch pollen washing water was prepared using $50 \mathrm{mg}$ pollen and adding $1 \mathrm{~mL}$ of ultrapure water. The suspension was treated the same way as the wood and leaf suspensions, except for centrifuging, which was done for $10 \mathrm{~min}$. Since we filtered our samples, all data presented refer to INM concentrations in the submicron size range (per mg sample mass, 


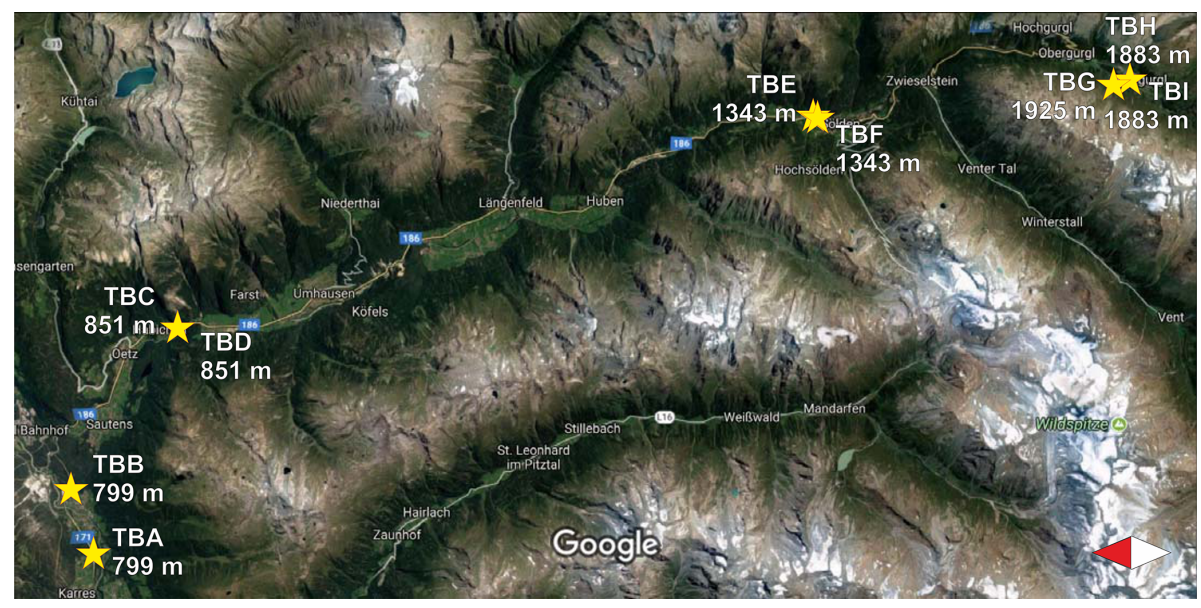

Figure 1. Sampling sites in Tyrol along a valley with an altitudinal gradient (adapted from Google Maps, https://www.google.com/maps, last access: 18 September 2017). Markings for TBH and TBI, as well as for TBC and TBD, completely overlap each other due to the close proximity of their growing sites.

extractable aqueously with a $50 \mathrm{mg} \mathrm{mL}^{-1}$ sample load within $6 \mathrm{~h})$.

\subsection{VODCA (Vienna Optical Droplet Crystallization Analyser)}

The Vienna Optical Droplet Crystallization Analyser (VODCA) was used to determine INA as described by Pummer et al. (2012). To monitor freezing of separated droplets, emulsions were created consisting of an aqueous phase in paraffin oil containing lanolin as emulsifier. As the aqueous part of the emulsion, ultrapure water was used for blank measurements and sample extracts were used for sample measurements. The emulsions were prepared on thin glass slides via mixing by hand with a pipette tip with oil in small excess, leading to aqueous droplets in an inert phase (Hauptmann et al., 2016). One glass slide was then placed on a Peltier element (Quick-cool QC-31-1.4-3.7M) with a thermocouple on its surface (next to the sample spot). The Peltier element was mounted on a copper cooling block cooled by an ice water cycle. The element and the cooling block were situated in an air-tight cell, which was closed during measurements. To prevent humidity from interfering with measurements, the cell was flushed with dry nitrogen gas whenever the sample was changed. To observe the freezing events we used an incident light microscope (Olympus BX51M) with an attached camera (Hengtech MDC320) linked to a computer.

Once the sample had been placed on the Peltier element and the cell was closed, the cooling process was started. All data presented here were obtained with a cooling rate of $10{ }^{\circ} \mathrm{C} \mathrm{min}-1$. To evaluate freezing, photos were taken during the whole process. The first one was always taken of the unfrozen sample as a blank. For each photo the respective sample temperature, $T_{\text {photo }}$, was recorded. Comparison of different photos made it possible to evaluate the number of frozen droplets and therefore the frozen droplet fraction at a certain temperature. Cooling continued until all droplets were frozen. Only droplets in the size range between 15 and $40 \mu \mathrm{m}$ (droplet volume: 1.8-34 pL) were included in our evaluation.

\subsection{Data analysis}

Results of the freezing experiments are presented as cumulative nucleus concentration (see below) and as mean freezing temperature (MFT). The MFT is the weighted average freezing temperature of all analysed droplets of a single aqueous sample extract, determined by the following equation:

$\mathrm{MFT}=\frac{\sum T_{i} \times n_{i}}{n_{-35^{\circ} \mathrm{C}}}$,

with $T_{i}$ being a recorded temperature, $n_{i}$ being the number of droplets freezing at this temperature, and $n_{-35^{\circ} \mathrm{C}}$ being the number of droplets frozen at temperatures of $-35^{\circ} \mathrm{C}$ and higher. The formula only accounts for temperatures of $-35^{\circ} \mathrm{C}$ and higher and consequently only for droplets frozen at these temperatures. This is done to minimize the risk of including homogeneous freezing events in our presented data.

The cumulative nucleus concentration $K\left(T_{\text {photo }}\right)$ was used as an indicator of the number of INM at temperatures above $T_{\text {photo }}$ contained in the sample. To determine INP concentrations, the number of frozen droplets $n_{\text {frozen }}$ for a given temperature $T_{\text {photo }}$ were counted. The droplet volume included in the evaluation was calculated for a droplet with a diameter of $25 \mu \mathrm{m}$ (median droplet diameter). To prevent an underestimation of the concentration of INM freezing at lower temperatures (Govindarajan and Lindow, 1988), samples showing no homogeneous freezing in the first measurement were diluted and re-measured. The measurements of diluted samples were only used for the determination of $K\left(T_{\text {photo }}\right)$, not for the MFT. 


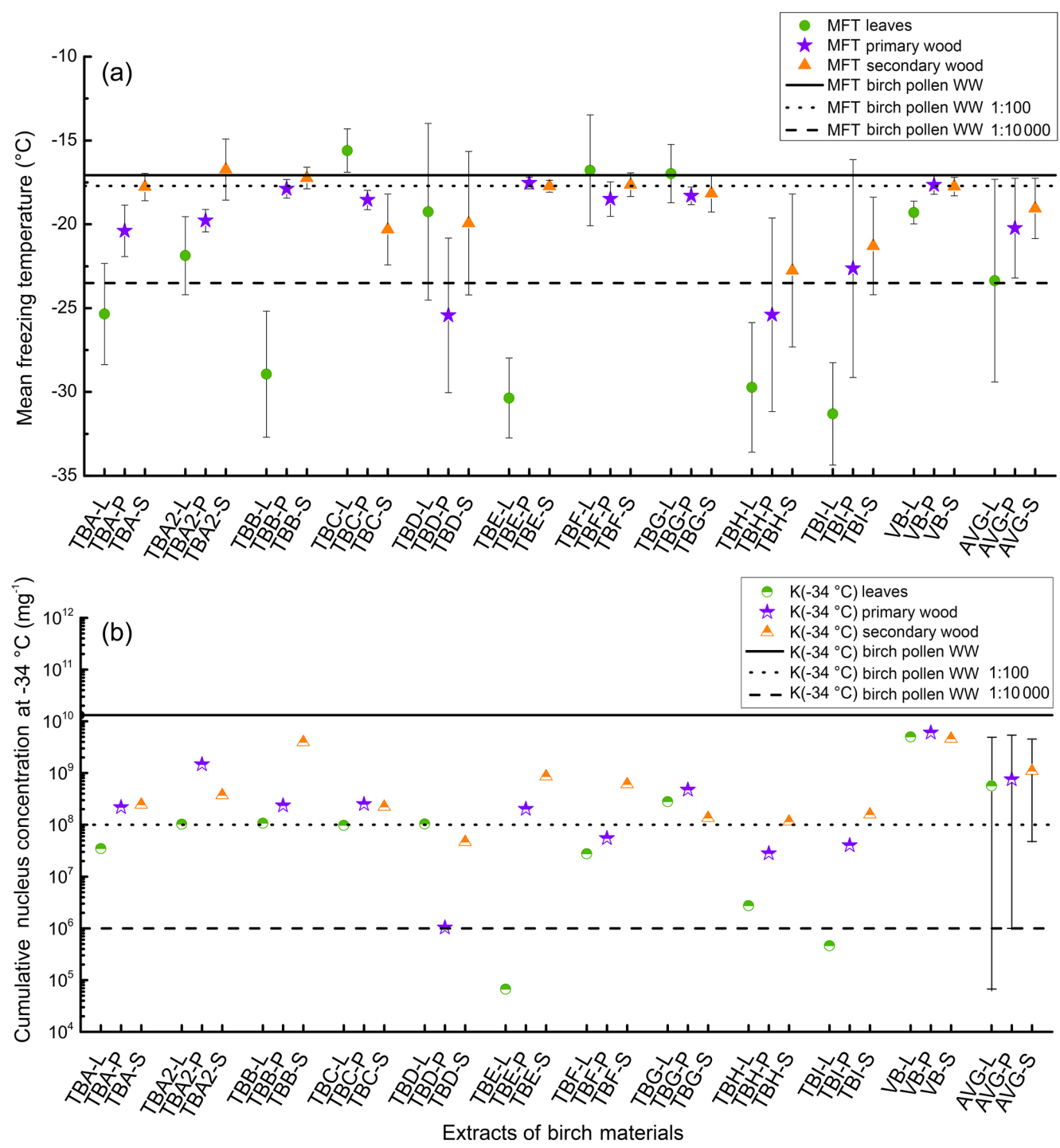

Figure 2. (a) Mean freezing temperature (MFT) of the different birch samples. Leaf extracts (L) are marked with green circles, primary wood extracts $(\mathrm{P})$ with violet stars, and secondary wood extracts $(\mathrm{S})$ with orange triangles. The solid line is the MFT of birch pollen washing water $\left(-17.1^{\circ} \mathrm{C}\right.$ with a standard deviation of $\pm 0.5^{\circ} \mathrm{C}$ (not plotted)). The dotted line represents the MFT of a dilution equivalent to $10^{8}$ INP mg ${ }^{-1}$ $\left(-17.7^{\circ} \mathrm{C}\right.$ with a standard deviation of $\pm 1.1^{\circ} \mathrm{C}$ (not plotted)) and the dashed line refers to the MFT of a dilution equivalent to $10^{6}$ INP mg ${ }^{-1}$ $\left(-23.5^{\circ} \mathrm{C}\right.$ with a standard deviation of $\pm 3.6^{\circ} \mathrm{C}$ (not plotted)). The three values on the far right side of (a) represent the average of all mean freezing temperatures for leaves (AVG-L), primary wood (AVG-P), and secondary wood (AVG-S) with the corresponding standard deviation. (b) Cumulative nucleus concentration at $-34^{\circ} \mathrm{C}\left(K\left(-34^{\circ} \mathrm{C}\right)\right)$ of the different birch samples $\mathrm{mg}^{-1}$ extracted sample. Assignment of the symbols is similar to the top plot. The solid line refers to the $K\left(-34^{\circ} \mathrm{C}\right)$ of birch pollen washing water mg ${ }^{-1}$ extracted pollen $\left(1.3 \times 10^{10} \mathrm{mg}^{-1}\right)$; the dotted and dashed line refer to the dilutions from birch pollen washing water introduced in (a). The three values on the far right side represent the average of all $K\left(-34^{\circ} \mathrm{C}\right)$ values. Error bars point to the area of trust, ranging from the highest to the lowest measured values.

The cumulative nucleus concentration is described as (Vali, 1971; Murray et al., 2012)

$K\left(T_{\text {photo }}\right)=-\frac{\ln \left(1-f_{\text {ice }}\right)}{V} \times d$,

with $f_{\text {ice }}$ being the frozen droplet fraction, $V$ the droplet volume ( $8.2 \mathrm{pL}$ for $25 \mu \mathrm{m}$ diameter), and $d$ the dilution factor.

$$
f_{\text {ice }}=\frac{n_{\text {frozen }}}{n_{\text {total }}},
$$

with $n_{\text {total }}$ being the total number of droplets and $n_{\text {frozen }}$ the number of frozen droplets. 
The cumulative nucleus concentrations are given over the whole temperature range; further, the concentration at $-34^{\circ} \mathrm{C}$ was used to compare different samples. Since we have never observed homogeneous freezing of ultrapure water at temperatures of $-34^{\circ} \mathrm{C}$ and higher with our setup, we attribute these values purely to heterogeneous freezing events.

\subsection{FTIR spectroscopy}

FTIR (Fourier-transform-infrared) spectroscopic measurements were conducted with a Vertex 80v (Bruker, Germany) containing an MCT (mercury cadmium telluride) detector cooled with liquid nitrogen. The optical bank was evacuated $(2.6 \mathrm{hPa})$ and had a GladiATR ${ }^{\mathrm{TM}}$ single-reflection ATR accessory unit (Pike, USA). The ATR unit contained a diamond crystal as total reflection window. OPUS 6.5 software was used for evaluation and instrument control. For each measurement, 128 scans were accumulated at a resolution of $0.5 \mathrm{~cm}^{-1}$. The crystal surface was flushed with dry nitrogen to prevent humidity from interfering with the measurements.

All three extracts of TBA as well as birch pollen washing water were measured at the same conditions by preparing a thin liquid layer of the extract and evaporating the contained water with a fan. The temperature on the surface of the crystal during evaporation was always below $35^{\circ} \mathrm{C}$. This process was repeated until the dried residues of approx. $20 \mu \mathrm{L}$ of the sample had been applied. IR spectra of all other extracts can be found in the supporting information (see Fig. S1-S3).

\section{Results}

\subsection{Freezing temperature and ice nuclei concentration}

All 30 extracts of birch trees were ice nucleation active (Fig. 2). The highest variation in MFT was found for the extracts from the leaves, which showed the highest (TBC$\mathrm{L}-15.6^{\circ} \mathrm{C}$ ) and lowest (TBI-L $-31.3^{\circ} \mathrm{C}$ ) MFTs amongst all analysed samples (Fig. 2). Of the 10 birch trees, the leaves of only 5 trees (TBC-L, TBD-L, TBF-L, TBG-L, VB$\mathrm{L})$ showed freezing temperatures close to the birch pollen line $\left(-17.1^{\circ} \mathrm{C}\right.$; see Fig. 2). Those samples froze between $-15.6^{\circ} \mathrm{C}$ (TBC-L) and $-19.3{ }^{\circ} \mathrm{C}$ (TBD-L and VB-L). The remainder of the analysed leaf extracts froze at temperatures of $-25.4{ }^{\circ} \mathrm{C}$ and below.

All primary wood extracts were ice nucleation active, with most MFT values between $-17.5^{\circ} \mathrm{C}$ (TBE-P) and $-22.6{ }^{\circ} \mathrm{C}$ (TBI-P). Further, two samples froze at $-25.4^{\circ} \mathrm{C}$ (TBH$\mathrm{P}$, TBD-P). For most secondary wood extracts, we found slightly higher MFTs than for the primary wood samples. The values ranged from $-17.2{ }^{\circ} \mathrm{C}$ (TBB-S) to $-22.8^{\circ} \mathrm{C}$ (TBH-S). The MFTs of the majority of the wood samples were close to the birch pollen line $\left(-17.1^{\circ} \mathrm{C}\right.$; see Fig. 2$)$.

However, it should be noted that a direct comparison between the different analysed samples and birch pollen wash-
Table 2. The results for the Wilcoxon-Mann-Whitney test. All given samples were shown to match birch pollen washing water or a dilution thereof. Pure birch pollen washing water is marked with pure, the $1: 100$ dilution equivalent to $10^{8} \mathrm{INP} \mathrm{mg}^{-1}$ is marked with $1: 100$, and the $1: 10000$ dilution equivalent to $10^{6} \mathrm{INP} \mathrm{mg}^{-1}$ is marked with $1: 10000 . n$ represents the number of data points used for comparison for each sample ${ }^{\mathrm{a}}$. The used significance level $\alpha^{\mathrm{b}}$ was $0.1 \%$.

\begin{tabular}{lrlr}
\hline & & $\begin{array}{l}\text { Birch pollen washing } \\
\text { water concentration }\end{array}$ & $p$-value \\
\hline TBB-S & 50 & Pure & $6.6 \times 10^{-3}$ \\
TBD-L & 70 & Pure & $2.8 \times 10^{-1}$ \\
TBA-S & 48 & $1: 100$ & $1.3 \times 10^{-3}$ \\
TBA-S2 & 118 & $1: 100$ & $2.7 \times 10^{-1}$ \\
TBD-P & 28 & $1: 10000$ & $8.3 \times 10^{-2}$ \\
TBH-P & 117 & $1: 10000$ & $1.9 \times 10^{-3}$ \\
TBH-S & 102 & $1: 10000$ & $1.3 \times 10^{-1}$ \\
TBI-P & 43 & $1: 10000$ & $6.6 \times 10^{-2}$ \\
\hline
\end{tabular}

\footnotetext{
a $n$ is equivalent to the number of droplets frozen homogeneously. $n$-values of the used standards were (pure washing water) $=96$, $n(1: 100)=135$, and $n(1: 10000)=92$.

$\mathrm{b}$ The significance level marks the probability of falsely assuming two populations to differ in their distribution.

${ }^{c}$ The $p$-value indicates the significance of the result. If the $p$-value is higher than the used significance level, the statistics indicate no difference between two distributions.
}

ing water is not straightforward, as the freezing behaviour of the washing water is highly dependent on its concentration. We observed freezing events for birch pollen washing water and its dilutions from $-15^{\circ} \mathrm{C}$ down to temperatures below $-35^{\circ} \mathrm{C}$, which marks the same temperature regime as the analysed birch samples exhibited freezing events. This effect is illustrated in Fig. 3, showing the freezing curves of pure birch pollen washing water and two dilutions, as well as their MFT and the corresponding standard deviation.

We compared the heterogeneous freezing regime of our samples (all freezing events down to $-35^{\circ} \mathrm{C}$ as defined in the data analysis section) to the heterogeneous freezing regime of pure washing water as well as to the two dilutions (which correspond to samples with $10^{8} \mathrm{INP} \mathrm{mg}^{-1}$ and $10^{6} \mathrm{INP} \mathrm{mg}^{-1}$ ) using the Wilcoxon-Mann-Whitney test. This is a non-parametric test which analyses whether the median of the distribution function of two populations can be differentiated (DePuy et al., 2005). The used $n$-values, which are the same as the number of droplets frozen heterogeneously during analysis of a sample, ranged between 28 and 118 for the correlated samples and between 92 and 135 for the standards. The $n$-values and gained data can be found in Table 2. It also gives the calculated $p$-values as results. The $p$-values are an indicator of the significance of the gained results. Calculated $p$-values above the set significance level $\alpha$ $(0.1 \%)$ indicate that the null hypothesis cannot be rejected. This means that no significant differences can be found between two distributions within the set level of significance. 

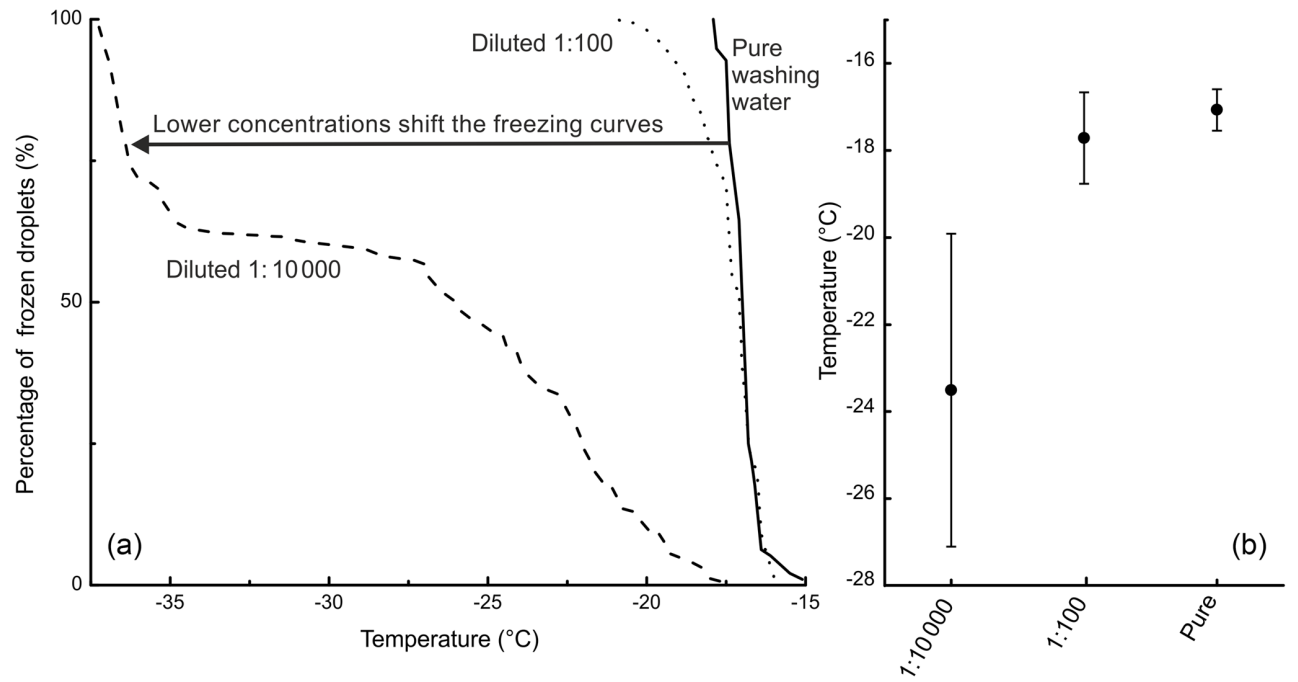

Figure 3. (a) The freezing curves of birch pollen washing water and two dilutions thereof (the dilution $1: 100$ is equivalent to $10^{8}$ INP $\mathrm{mg}^{-1}$; the dilution $1: 10000$ is equivalent to $10^{6} \mathrm{INP} \mathrm{mg}^{-1}$ ) with the fraction of frozen droplets as a function of temperature. (b) The MFT with the corresponding standard deviations of the birch pollen washing water and the two analysed dilutions.

Similarities were shown by the test for the pure washing water with TBB-S and TBD-L. These two samples belong to the samples tested with the highest activity, which are similar to pure birch pollen washing water. With the dilution equivalent to $10^{8} \mathrm{INP} \mathrm{mg}^{-1}$, the test shows similarities for both TBA-S and TBA-S2, and with the dilution equivalent to $10^{6} \mathrm{INP} \mathrm{mg}^{-1}$ the test shows similarities for TBD-P, TBH-P, TBH-S, and TBI-P. The latter are among the samples tested with the lowest activity and these samples match a strong dilution of birch pollen washing water (approx. $1: 10000$ ) with only weak activity left (see Fig. 3).

The cumulative nucleus concentration $K\left(T_{\text {Photo }}\right)$ showed a trend similar to the MFT (as depicted for $-34^{\circ} \mathrm{C}$ in Fig. 2, and for all temperatures above $-35^{\circ} \mathrm{C}$ in Fig. 4). Leaf extracts mostly exhibited cumulative nucleus concentration at $-34^{\circ} \mathrm{C}$ between $2.8 \times 10^{6} \mathrm{mg}^{-1}$ (TBH-L) and $5.0 \times 10^{9} \mathrm{mg}^{-1}$ (VB-L), with two outliers exhibiting $4.6 \times$ $10^{5} \mathrm{mg}^{-1}$ (TBI-L) and $6.7 \times 10^{4} \mathrm{mg}^{-1}$ (TBE-L). However, these two outliers with the low INM concentration were the two leaf samples exhibiting the lowest MFT values (TBE-L $-30.4^{\circ} \mathrm{C}$, TBI $-31.3^{\circ} \mathrm{C}$ ). This indicates that the unusually low MFTs are a result of low concentrations of INM in the sample. Leaf extracts, which exhibited the highest variation in MFT, also exhibited the highest variation in INM concentration (see Figs. 2, 4, and 5).

The dotted line in the lower panel refers to the $K\left(-34^{\circ} \mathrm{C}\right)$ value of birch pollen washing water $\left(1.3 \times 10^{10} \mathrm{mg}^{-1}\right)$. Presented data show that the samples with the highest $K\left(-34{ }^{\circ} \mathrm{C}\right)$ values (TBB-S, and all samples from the Viennese birch) contain similar amounts of INP mg ${ }^{-1}$ extracted sample. For primary wood extracts, most values for $K\left(-34^{\circ} \mathrm{C}\right)$ ranged between $1.0 \times 10^{6} \mathrm{mg}^{-1}$ (TBD-P) and $6.1 \times 10^{9} \mathrm{mg}^{-1}$ (VB-P). Secondary wood extracts again ex- hibited the least variation, which can be seen best in Figs. 2, 4 and 5. Their cumulative nucleus concentrations at $-34^{\circ} \mathrm{C}$ ranged from $4.6 \times 10^{7}$ (TBD-S) to $4.6 \times 10^{9} \mathrm{mg}^{-1}$ (VB-S, TBB-S). Figure 4 shows that this decreased variation compared to the other samples is not just true for the cumulative nucleus concentration at $-34^{\circ} \mathrm{C}$, but also over the whole temperature regime.

The averages of MFT and cumulative nucleus concentration (Fig. 2) show a similar trend. Leaves exhibited the lowest freezing temperature and cumulative concentration, followed by primary wood, and secondary wood exhibited the highest values in both categories. This points towards a relationship between concentration and freezing temperature, as has already been observed for the birch pollen extracts.

To examine the INP distribution within a tree, a second branch of TBA was prepared and measured according to the described protocol. Resulting data are presented in Fig. 2 and marked with a 2 (TBA-L2, TBA-P2, and TBA-S2). Primary and secondary wood extracts are well in line regarding their freezing temperatures (TBA-P $-20.4{ }^{\circ} \mathrm{C}$, TBA-P2 $-19.8^{\circ} \mathrm{C}$; TBA-S $-17.8^{\circ} \mathrm{C}$, TBA-S $2-16.7^{\circ} \mathrm{C}$ ); however, the primary wood from the second analysed branch contained higher INP concentrations (TBA-P $2.2 \times 10^{8} \mathrm{mg}^{-1}$, TBA-P2 $1.5 \times 10^{9} \mathrm{mg}^{-1}$; TBA-S $2.4 \times 10^{8} \mathrm{mg}^{-1}$, TBA-S2 $\left.3.7 \times 10^{8} \mathrm{mg}^{-1}\right)$. Leaves varied in their freezing temperatures and cumulative nucleus concentrations (TBA-L $-25.3^{\circ} \mathrm{C}$ and $3.5 \times 10^{7} \mathrm{mg}^{-1}$, TBA-L2 -21.8 and $\left.1.0 \times 10^{8} \mathrm{mg}^{-1}\right)$.

Further, we analysed the relationship of the extractable INM concentration and the extractable total mass. The total extractable mass (given as dry mass in Fig. 5) describes the weight of the dry residue of a filtered extract in $\mathrm{mg} \mathrm{mL}^{-1}$. It was highest for leaf extracts and lowest for the secondary wood extracts. As in the other attributes, leaf extracts ex- 

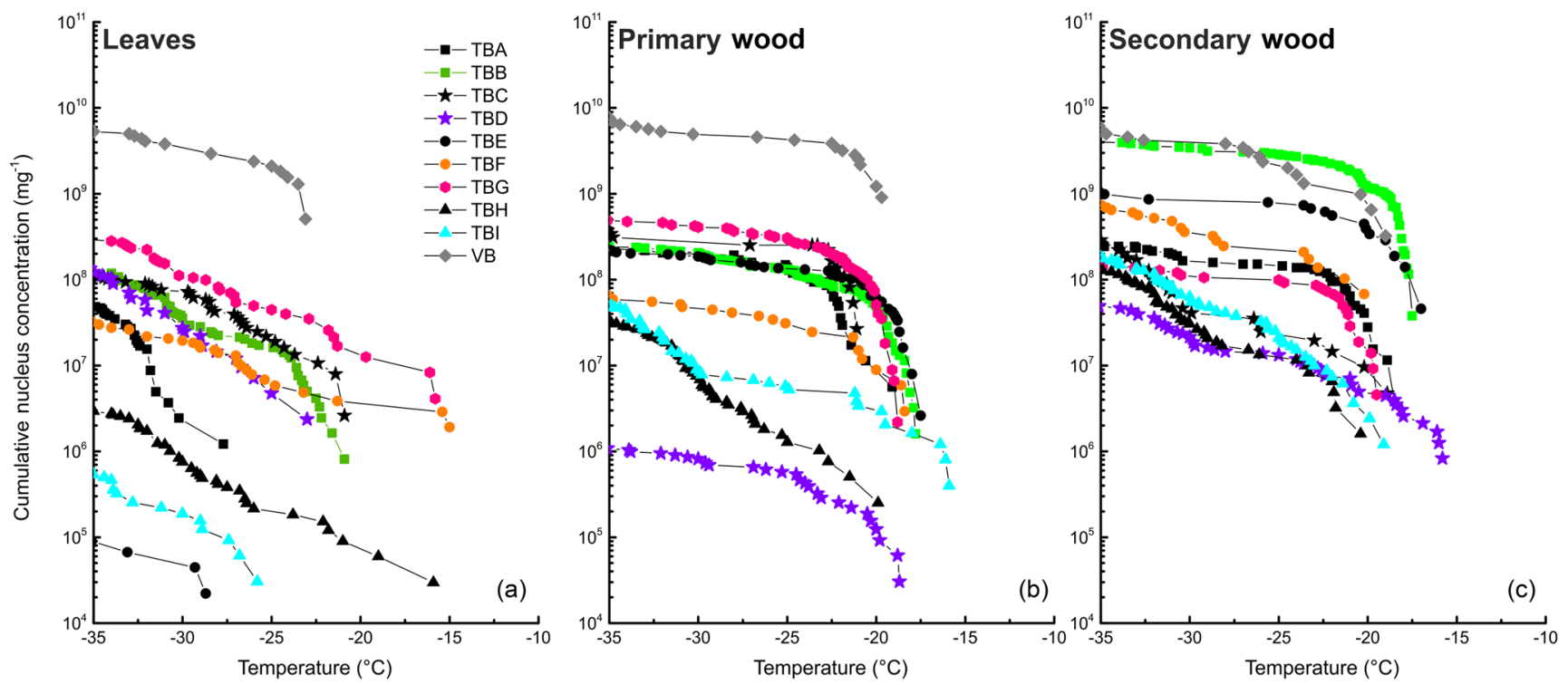

Figure 4. Cumulative nucleus concentration as a function of temperature for leaf extracts (a), primary wood extracts (b), and secondary wood extracts (c). The diagram is cut off at $-35^{\circ} \mathrm{C}$, since we cannot contribute freezing events below this temperature to heterogeneous nucleation. The symbols used for the different data points are grouped. Birches growing in close proximity under similar conditions are marked with the same symbol (different fillings).

hibited the highest variations, with dry masses ranging from 11 (TBE-L) to $19 \mathrm{mg} \mathrm{mL}^{-1}$ (TBG-L), followed by primary wood extracts ranging from 7 (VB-S) to $13 \mathrm{mg} \mathrm{mL}^{-1}$ (TBGP). Dry masses of the secondary wood extracts ranged from 6 (TBD-S, TBE-S. TBF-S, VB-S) to $11 \mathrm{mg} \mathrm{mL}^{-1}$ (TBH-S). The secondary wood samples tended to exhibit the highest concentrations of INM mg ${ }^{-1}$ sample mass; they also had the highest ratio of INM compared to dry mass (see Fig. 5). The lowest ratio was found for the leaf extracts.

While our results show that all analysed birch trees were ice nucleation active, we also found that the trees themselves vary in their activity if compared to each other. We found the lowest concentrations of INM (if all samples are regarded) for TBD, TBH, and TBI (see Figs. 2 and 4), all of which were growing along a riverbank with no traffic next to the trees. Only one tree with these growing conditions was found to exhibit high INM concentrations (TBC). Highest concentrations were found in the samples of the Viennese birch, located in a small park in Vienna, surrounded by heavy traffic. We found that trees, which were growing in close proximity to each other (see Fig. 1), often exhibited comparable INA. This is especially true for TBA and TBB, as well as TBH and TBI. TBE and TBF match each other well except for the INA of the analysed leaves. TBC and TBD however acted significantly differently if compared to each other, with TBD showing decreased INM concentrations.

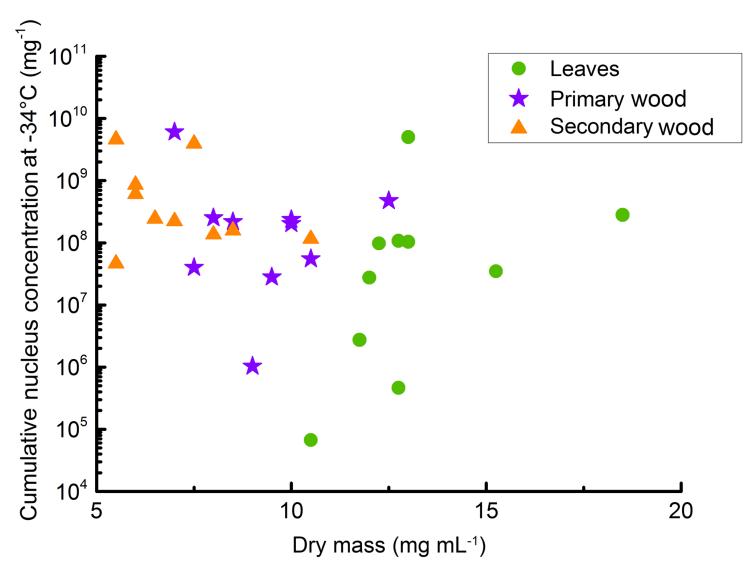

Figure 5. Scatterplot of dry mass (dry residues of the different filtered extracts) and cumulative nucleus concentration at $-34{ }^{\circ} \mathrm{C}$ per sample mass. The dry mass is the mass we were able to extract with the $50 \mathrm{mg} \mathrm{mL}^{-1}$ suspensions. The data show that secondary wood, which contained mostly the highest INM concentrations and lowest variations between different samples, also contained the lowest extractable mass. Therefore INM ratios in the extractable content of the different samples were highest in secondary wood samples.

\subsection{Heat treatment}

To analyse the similarities to birch pollen washing water, all three extracts of TBA were treated at $100^{\circ} \mathrm{C}$ following the protocol introduced by Pummer et al. (2012). Therefore, $100 \mu \mathrm{L}$ of each extract were applied on a clean glass slide and put in an oven set to $100^{\circ} \mathrm{C}$. After $1 \mathrm{~h}$ the dry 
Table 3. Band assignment of the IR spectra of TBA extracts (leaves, primary wood, and secondary wood) and birch pollen washing water (Miyazawa et al., 1956; Kačuráková et al., 2000; Schulz and Baranska, 2007; Chen et al., 2010; Pummer et al., 2013).

\begin{tabular}{ll}
\hline $\begin{array}{l}\text { Band wavenumber } \\
\left(\mathrm{cm}^{-1}\right)\end{array}$ & Assignment of IR spectra \\
\hline 3300 & O-H stretch/N-H stretch \\
2940 & C-H stretch \\
2890 & C-H stretch \\
2700 & O-H stretch \\
1720 & C=O, xylan \\
1650 & C=O stretch, C=C, amide I \\
1600 & C=O stretch (lignin), C=C, amide I \\
1510 & C=O stretch (lignin), amide II \\
1450 & CH deformation (lignin and xylan) \\
1425 & Aromatic skeletal combined with C-H \\
1350 & C-H deformation (ring) \\
1300 & N-H C-H deformation, amide III \\
1270 & C=O stretch (lignin), amide III \\
1240 & C-O, C-N, C-N-C, C-C-O of phenolic compounds, amide III \\
1200 & Phosphate, C-C-O of phenolic compounds \\
1140 & C-O-C stretching (pyranose rings), C=O stretching (aliphatic groups), \\
& guanine, tyrosine, tryptophane \\
1110 & Sugar skeletal vibration \\
1070 & C-H stretch, C-C stretch \\
1050 & C-H stretch, C-C stretch, guaiacyl units (lignin) \\
990 & OCH (polysaccharides) \\
920 & C=C, cellulose P-chains, polysaccharides $-\beta$-linkage, phenolic compounds \\
850 & C-O-C skeletal mode (polysaccharides $-\alpha$-linkage, COPOC RNA, phenolic compounds \\
810 & C=O deformation (polysaccharides), phenolic compounds \\
770 & Phosphate stretch \\
\hline
\end{tabular}

residues were resuspended in $100 \mu \mathrm{L}$ of ultrapure water each and analysed for INA. The results of this experiment are given in Fig. 6 as MFT and $K\left(-34^{\circ} \mathrm{C}\right)$ values. The corresponding values of the untreated TBA extracts are plotted for comparison. We find no major changes in the mean freezing temperatures (TBA-L $-25.4^{\circ} \mathrm{C}$, TBA-L treated $-26.1^{\circ} \mathrm{C}$; TBA-P $-20.4^{\circ} \mathrm{C}$, TBA-P treated $-20.9^{\circ} \mathrm{C}$; TBA$\mathrm{S}-17.8^{\circ} \mathrm{C}$, TBA-S treated $\left.-18.2^{\circ} \mathrm{C}\right)$ or $K\left(-34^{\circ} \mathrm{C}\right)$ values (TBA-L $3.5 \times 10^{7} \mathrm{mg}^{-1}$, TBA-L treated $4.1 \times 10^{7} \mathrm{mg}^{-1}$; TBA-P $2.2 \times 10^{8} \mathrm{mg}^{-1}$, TBA-P treated $1.5 \times 10^{8} \mathrm{mg}^{-1}$; TBA$\mathrm{S} 2.4 \times 10^{8} \mathrm{mg}^{-1}$, TBA-S treated $1.8 \times 10^{8} \mathrm{mg}^{-1}$ ).

\subsection{FTIR spectroscopy}

FTIR spectroscopy was used to examine similarities in chemical composition between the extracts of TBA (leaves, primary and secondary wood) and aqueous birch pollen extract. The normalized FTIR spectra are shown in Fig. 7. Table 3 contains assignments for the band positions. On the left side of the spectrum, there is a broad band with a maximum at approx. $3300 \mathrm{~cm}^{-1}$ typical for $\mathrm{NH}$ and $\mathrm{OH}$ stretching vibrations, and further, a bisected band with maxima at 2940 and $2890 \mathrm{~cm}^{-1}$, which can be assigned to aliphatic $\mathrm{CH}$ stretching vibrations. All four spectra show a weak shoulder at approx- imately $2700 \mathrm{~cm}^{-1}$ which is linked to $\mathrm{OH}$ stretching vibrations. On the low-frequency side $\left(1800-750 \mathrm{~cm}^{-1}\right)$ we find a broad array of bands. We assigned 19 maxima. Several of these bands are typical for saccharides as well as for xylan. We also found bands in all three typical amide regions. All three regions are consistent with other biomolecules (see Table 3) as well; therefore the presence of peptides is not entirely clear. The spectra of the different extracts of TBA (Fig. 7) show a strong resemblance to each other, but we find three main differences. (a) The intensity at $1510 \mathrm{~cm}^{-1}$ : while the band is strongly visible in the spectrum of secondary wood extracts, it is much less pronounced in the spectra of primary wood and leaf extracts. (b) The band at $1070 \mathrm{~cm}^{-1}$ is strongest visible for the leaf extract, where it nearly swallows its neighbour at $1110 \mathrm{~cm}^{-1}$, while it is only present as a slight shoulder for the wood extracts. (c) The region of $920 \mathrm{~cm}^{-1}$ and below increases in intensity from leaf extract over primary wood extract to secondary wood extract.

Comparing the birch pollen washing water to the TBA extracts, we see an enhancement of the low-frequency side of the spectrum. We find all maxima present in the pollen washing water spectrum also in the other extracts. However, some bands, which are clearly pronounced in the pollen spectrum, are only very weak shoulders in the TBA extract spec- 


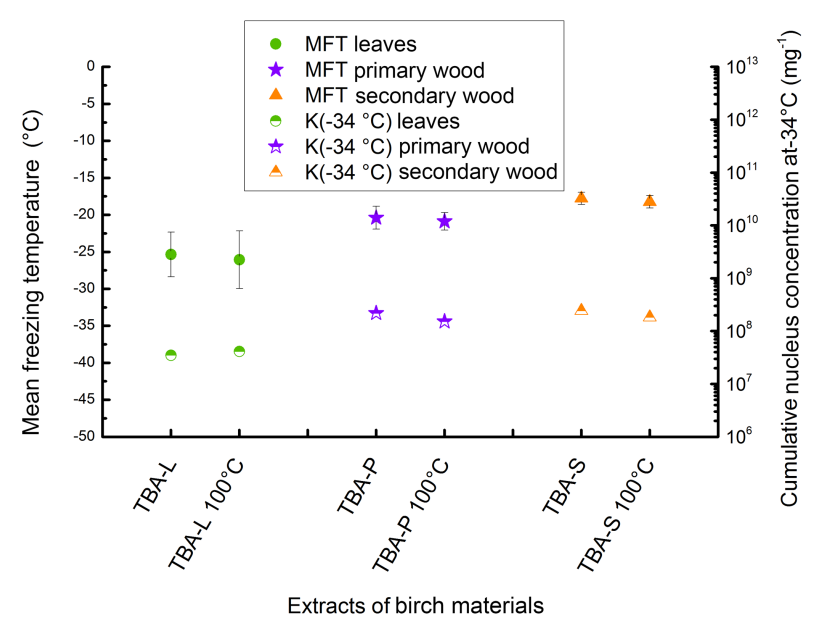

Figure 6. Results of the heat treatment of the different TBA extracts. Leaves are marked with green circles, primary wood with violet stars, and secondary wood with orange triangles. The left value belongs to the untreated sample, the right value to the sample treated with $100^{\circ} \mathrm{C}$ for $1 \mathrm{~h}$. Filled symbols represent the mean freezing temperature and correlate with the left $y$ axis; half-filled symbols represent the cumulative nucleus concentration as $-34^{\circ} \mathrm{C} \mathrm{mg}^{-1}$ extracted sample and correlate with the right $y$ axis.

tra $\left(1350,1300,1270,1200,1140,810\right.$, and $\left.770 \mathrm{~cm}^{-1}\right)$. Furthermore, we find the maxima of the two most pronounced bands ( 3300 and $1050 \mathrm{~cm}^{-1}$ given for the TBA extracts) to be shifted slightly by approx. $25 \mathrm{~cm}^{-1}$. The spectra of all analysed samples are given in Figs. S1-S3. They show the same features as the spectra given for TBA, with varying intensity ratios.

\section{Discussion}

We examined the INA of samples from 10 different birch trees (Betula spp.) to extend the knowledge on their freezing behaviour. Samples were taken from nine birch trees in Tyrol, Austria, and from one tree in a small urban park in Vienna, Austria. Filtered aqueous extracts of 30 samples of leaves, primary wood, and secondary wood were analysed for INA using VODCA, an emulsion technique. All of the samples from milled birch branches contained INM in the submicron size range. INM of a similar size range were previously found in other biological material including fungi and leaf litter (Schnell and Vali, 1973; Fröhlich-Nowoisky et al., 2015; O'Sullivan et al., 2015), as well as birch pollen (Pummer et al., 2012, 2015). Our results extend these previous observations and demonstrate that aboveground material from the birch tree (and not just the pollen) can produce INM.

Several studies have found that organic components can increase the INA of soil and dust (Conen et al., 2011; O'Sullivan et al., 2014, 2016; Tobo et al., 2014; Hill et al., 2016). Such organic components could be provided by INM released by birch trees, which could stick to inactive particles, and thus enhance their INA. Cracks and wounds on the surface could allow the INP to be washed off the surface of twigs and leaves into the soil. This marks a potential to influence the INA of mineral dust and soil particles and act as INP in the atmosphere. Huffman et al. (2013) observed increased INP concentrations after rain events related to a burst in concentrations of biological particles. INM released from plants such as birch play an important role in this process. Further studies on possible release pathways of the INP from birches into the surrounding environment are necessary to quantify such effects.

The freezing temperature observed for the aqueous birch pollen extract $\left(-17.1^{\circ} \mathrm{C}\right.$; see Fig. 2) is in line with values reported in the literature for aqueous birch pollen extracts (reported freezing events are generally between -15 and $-23{ }^{\circ} \mathrm{C}$; Diehl et al., 2001; Pummer et al., 2012; Augustin et al., 2013; O'Sullivan et al., 2015). Interestingly, most of our samples froze in the same temperature range between -15 and $-23^{\circ} \mathrm{C}$. Half of the leaves (TBC-L, TBD-L, TBF-L, TBG-L, and VB), 8 out of 10 primary wood samples (TBA-P, TBB-P, TBC-P, TBE-P, TBF-P, TBG-P, TBI$\mathrm{P}$, and TBV-P), and all secondary wood samples exhibited a mean freezing temperature in this temperature window. If we broaden the temperature window by including dilutions of birch pollen washing water, we observe freezing events happening down to $-35^{\circ} \mathrm{C}$. Nearly all freezing events recorded for the presented samples freeze in this temperature window between -15 and $-35^{\circ} \mathrm{C}$. Leaves only occasionally show higher freezing events (see Fig. 2). The WilcoxonMann-Whitney test shows similarities between more than a quarter of our samples and birch pollen washing water as well as the respective dilutions (see Table 2). These samples showed some of the highest and lowest MFT values measured (e.g. TBB-S, the best secondary wood sample matches pure washing water, while the lowest, TBH-S, matches the dilution of birch pollen washing water, which is equivalent to $10^{6} \mathrm{INP} \mathrm{mg}^{-1}$ ). As we were able to match some of the most and least active samples, we conclude that there is a correlation for each sample between concentration of INP and freezing temperature relating to the birch pollen washing water. Moreover, we observed heat resistance at $100^{\circ} \mathrm{C}$, similar to the results of Pummer et al. (2012). This indicates a resemblance between the INM from pollen and those found in the extracts of leaves, primary wood, and secondary wood. The data show that the average freezing temperatures of secondary wood, primary wood, and leaves differ slightly. These differences however follow the same pattern as the INM concentration. Therefore we assume this to be a concentration effect. Based on these results, we hypothesize that the INM in birch, which are found in leaves, primary wood, and secondary wood, behave similarly and can be statistically related to the INM found in birch pollen. This means that INM from birch trees are not just relevant during the pollen season but over a longer period of time, possibly even over the whole 

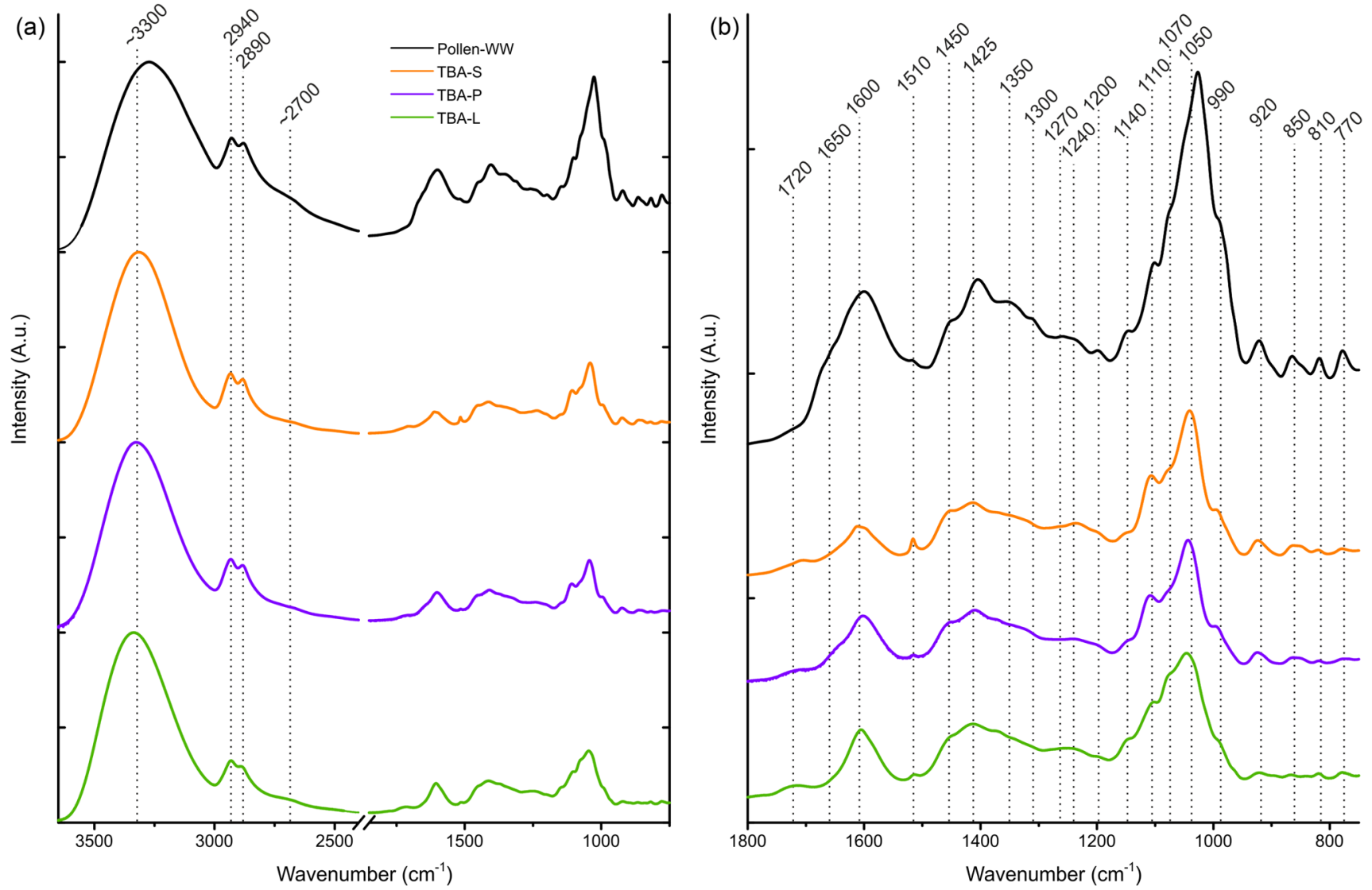

Figure 7. FTIR spectra of the TBA extracts (leaves in green, primary wood in violet, and secondary wood in orange) and birch pollen washing water (black). (a) The whole spectrum between 3650 and $750 \mathrm{~cm}^{-1}$. (b) Enlarged right side of the spectrum between 1800 and $750 \mathrm{~cm}^{-1}$. Possible band assignments are given in Table 3.

year. It is important to conduct further research on the seasonal dependency of the production of INM of birch trees.

We observed a high variability of INM in leaves. Even for leaves of two branches of the same tree, we found differences in their freezing temperatures. Only 5 out of 10 samples froze at similar temperatures to the INM from birch pollen. The high variability could be explained by external impacts, as leaves are easily influenced by their growing conditions. Leaves growing in the shade exhibit reduced dry masses and nitrogen content (Eichelmann et al., 2005). Also, their hydrological conductivity is impacted by radiation (Sellin et al., 2011). Further, the growing site next to a river typically leads to enhanced water availability, which can cause increased leaf conductivity and transpiration rate in the lower crown foliage of trees (Sellin and Kupper, 2007).

Birches are native through most of Europe, even up to central Siberia, and are capable of growing in boreal regions and at high altitudes (Beck et al., 2016). Due to climate change and their resistance against cold climate, some birches can even be found above the tree line (Truong et al., 2007). Due to this vast distribution area, the growing conditions of birches may vary greatly. We speculate that environ- mental conditions may influence the production and release of INM from birch. Many environmental factors can affect the plant physiology and growth, e.g. humidity (Sellin et al., 2013), atmospheric ozone (Maurer and Matyssek, 1997; Harmens et al., 2017), $\mathrm{CO}_{2}$ (Rey and Jarvis, 1998; Kuokkanen et al., 2001), $\mathrm{NO}_{x}$ and $\mathrm{SO}_{2}$ (Freer-Smith, 1985; Martin et al., 1988), as well as exposure to light and its wavelength (Eichelmann et al., 2005; Sellin et al., 2011). All of these factors might also influence the INM production of birch trees. The extracts of branches showed a systematic distribution of INM that could relate in part to their growth environment. Wood samples of the birches' TBD, TBH, and TBI (see Fig. 2), all three of which were growing next to a river, froze at lower temperatures than the other birch samples. Moreover, there was a tendency for birch trees located near roads (TBA, TBB, TBE, TBF, and VB grew directly next to roads) to be associated with increased INA. TBE and TBF grew next to a road and a river, but showed comparable INM concentrations to the other roadside birches. If the INA of birches is based on a stress or defence mechanism, this could be due to stress caused by the exhaust of traffic, e.g. $\mathrm{NO}_{x}$, which is an important pollutant released by traf- 
fic (Franco et al., 2013). It has the potential to harm plants, but can also be absorbed by many plants and used as a nitrogen source (Allen Jr., 1990). Other than roads and rivers in close proximity, the tree altitude was not correlated with INA. Future investigations of birch trees located across different altitudes, roads, settlements, and forests are warranted.

Some investigations on birch stands showed a dry weight of 2 to $25 \mathrm{tha}^{-1}$ for twigs and 1 to $8 \mathrm{tha}^{-1}$ for leaves (Johansson, 1999; Uri et al., 2007). This leads to estimated INP concentrations of the order of $10^{16}$ to $10^{19} \mathrm{ha}^{-1}$ for twigs and $10^{14}$ to $10^{18} \mathrm{ha}^{-1}$ for leaves. Plant debris can be an important constituent of ambient particulate matter (Matthias-Maser and Jaenicke, 1995; Andreae, 2007; Winiwarter et al., 2009). However, the underlying processes of the release of plant debris into the atmosphere are not fully understood, making predictions of their atmospheric impact hard (Andreae, 2007; Winiwarter et al., 2009). Sánchez-Ochoa et al. (2007) analysed atmospheric aerosols collected at various background sites in Europe and used cellulose as a proxy for plant debris. They found biannual average concentrations of 33.4$363 \mathrm{ng} \mathrm{m}^{-3}$ air. Especially the leaves of birch trees could be an important source of INP as they are shed and produced annually. Decaying leaf litter is known to be a good source of INP (Schnell and Vali, 1973). Conen et al. (2016, 2017) showed that air masses passing over land can be enriched with INP derived from such leaf litter. Collectively, these studies underscore the importance of plants as sources of INP.

Since all the analysed materials are of natural origin, we cannot rule out that some contamination could play a role in the INA of our extracts. Some bacteria have been found to act as INP (e.g. Pseudomonas syringae, Maki et al., 1974); however, these bacteria are typically in the size range $>1 \mu \mathrm{m}$ (Monier and Lindow, 2003) and therefore easily filtered with the $0.2 \mu \mathrm{m}$ syringe filter. Further, some lichen are known to exhibit INA (Kieft, 1988), and some microorganisms release their small contained INP in the aqueous phase, e.g. Mortierella alpina (Fröhlich-Nowoisky et al., 2015), which cannot be filtered with used methods. However, most known ice nucleation active lichens and microorganisms as well as released INP typically freeze at significantly higher temperatures (above $-10^{\circ} \mathrm{C}$, Maki et al., 1974; Kieft, 1988; Pouleur et al., 1992; Murray et al., 2012; Fröhlich-Nowoisky et al., 2015) than the freezing temperatures observed for our samples, with very few exceptions (Iannone et al., 2011). As the highest onset temperature observed in our measurements was $-14.1^{\circ} \mathrm{C}$ (TBC-L), the onset temperature of birch pollen washing water was quite close to this value $\left(-15.1^{\circ} \mathrm{C}\right)$, and heat treatment did not affect the extracts of TBA, we do not suspect significant contamination of our samples. However, the INA of birches, especially if growing close to a road or in urban regions, could be affected by soot and other anthropogenic emissions, as soot can act as INP (DeMott, 1990; Murray et al., 2012).
The measured FTIR spectra indicate that the birch extracts are chemically similar to each other, and to pure birch wood. As plants not only contain polysaccharides but also several soluble carbohydrates (Magel et al., 2000), we assume those substances to play an important role in the chemical composition of our extracts. Fitting to this assumption, most of the bands found in our spectra could be assigned to carbohydrates and polysaccharides. Presented spectroscopic data matched the literature well (Chen et al., 2010; Pummer et al., 2013; Dreischmeier et al., 2017); however, intensity ratios varied. IR spectra from birch pollen and TBA extracts (Fig. 7) show strong similarities to the spectrum of milled birch wood shown by Chen et al. (2010) (measured in $\mathrm{KBr}$ pellets). In particular, the range between 1150 and $1300 \mathrm{~cm}^{-1}$, i.e. especially the band at $1270 \mathrm{~cm}^{-1}$, was strongly enhanced compared to our spectra. Also, the band at $1510 \mathrm{~cm}^{-1}$ was very intense in the pure wood spectrum compared to the extracts. Both bands are representative of lignin, a main substance in wood that is only weakly soluble in water. Since the remaining weak bands can be assigned to other structural elements, our extracts likely did not contain any lignin. Other than the lignin bands, our aqueous extracts show very similar spectroscopic features compared to the pure wood samples. These similarities between the spectra of extracts and the spectrum of pure wood indicate that our extract method retrieves the majority of components, leading to a similar distribution of bands, with differing intensities due to differences in concentration. The IR spectrum of birch pollen washing water (Fig. 7) is in good agreement with the literature data (Pummer et al., 2013; Dreischmeier et al., 2017). The extracts of the different TBA samples (leaves, primary wood, and secondary wood) exhibit similar spectra with no major differences. The birch spectra of birch pollen washing water and the different wood extracts match well, showing very similar maxima with mostly minor differences in intensity ratios.

In the FTIR spectroscopy data, we found strong similarities between birch pollen washing water and the different aqueous extracts from the TBA samples. Further comparison with whole pollen grains, as well as with pure wood, as found in the literature, shows strong similarities in the spectroscopic features of our different birch samples. As not just the band position, but also the intensity ratios, agree with each other, we assume this to indicate that we are able to extract the major components found in wood with our extraction method and that the pollen and wood sample extracts exhibit chemical similarities to a certain extent.

Only little INP are known to trigger freezing above $-10^{\circ} \mathrm{C}$, which are typically biological substances such as bacteria (Murray et al., 2012). Below $-10^{\circ} \mathrm{C}$, birch pollen belong to the group of highest freezing temperatures, with onset higher than most mineral dusts, ash, and soot samples (Murray et al., 2012). The vast majority of atmospheric INP and INP retrieved from precipitation samples exhibit freezing temperatures below $-10^{\circ} \mathrm{C}$ (DeMott et al., 2010; Petters and 
Wright, 2015). The identity of the INP released from birches is still unclear. Pummer et al. (2013) showed that proteins, saccharides, and lipids are easily extracted aqueously from birch pollen. While Pummer et al. (2012) and Dreischmeier et al. (2017) speculate that the responsible molecules are carbohydrates, Tong et al. (2015) attribute the highest INA to extracted proteins. Hiranuma et al. (2015) showed that cellulose, a polysaccharide which is ubiquitous in plants, exhibits INA in the same temperature range. With our spectroscopic data, we found strong indicators for saccharides being present, including prominent bands which could be associated with cellulose. Further, we found bands in the most prominent protein regions, though those could be assigned to other molecule groups.

\section{Conclusion}

The ice nucleation activity of ten different birch trees $(B e$ tula spp.) were examined. Filtered aqueous extracts of 30 samples of leaves, primary wood, and secondary wood were analysed for INA using VODCA, an emulsion technique. All samples contained ice nuclei in the submicron size range. Concentrations of ice nuclei ranged from $6.7 \times 10^{4}$ to $6.1 \times 10^{9} \mathrm{mg}^{-1}$. Mean freezing temperatures varied between -15.6 and $-25.4^{\circ} \mathrm{C}$ (excluding three samples that exhibited lower freezing temperatures). Comparing the freezing behaviour of our samples to birch pollen washing water and two dilutions $(1: 100$ and $1: 10000)$ using the Wilcoxon-MannWhitney test, we found statistical correlations for more than a quarter of our samples and birch pollen washing water, indicating a relationship between the INM of wood, leaves, and pollen. As we were able to match some of the most and least active samples, we conclude that given the right dilution of birch pollen washing water, all samples could be matched. The majority of the samples showed freezing temperatures close to those of birch pollen extract, indicating a relationship between the INM of wood, leaves, and pollen. Extracts derived from secondary wood showed the highest concentrations of INM and the highest freezing temperatures. Extracts from the leaves exhibited the highest variation in INM and freezing temperatures. Infrared spectra of the extracts suggest that the aqueous extracts of birch materials tested showed similarities to aqueous extracts of birch pollen. Our results suggest that there might be linkages between INA, growing site, and condition of the birch tree, with streets exhibiting a positive influence and rivers tending to exhibit a negative influence on INA. Field and laboratory studies are needed to examine how much ice nucleation active material can be expected per surface area of a tree and which quantity of this material can be aerosolized. A broader selection of samples is also needed to further examine differences between different trees and an influence of growing site and season.
Data availability. The raw data can be found via the Zenodo online repository at https://doi.org/10.5281/zenodo.1461817 (Felgitsch et al., 2018).

Supplement. The supplement related to this article is available online at: https://doi.org/10.5194/acp-18-16063-2018-supplement.

Author contributions. LF, HG, and DGSIII designed the experimental study. LF, PB, MM, MEM, TMS, and PW performed the experiments. LF, JB, DGSIII, and HG wrote the manuscript.

Competing interests. The authors declare that they have no conflict of interest

Acknowledgements. The authors would like to thank the FWF (Austrian Science Fund, project no. P 26040) and the FFG (Austrian Research Promotion Agency, project no. 850689) for funding.

Edited by: Ryan Sullivan

Reviewed by: two anonymous referees

\section{References}

Allen Jr., L. H.: Plant responses to rising carbon dioxide and potential interactions with air pollutants, J. Environ. Qual., 19, 1534, https://doi.org/10.2134/jeq1990.00472425001900010002x, 1990.

Andreae, M. O.: Aerosols before pollution, Science, 315, 50-51, https://doi.org/10.1126/science.1136529, 2007.

Anilkumar, V. S., Dinesh Babu, K. V., Sunukumar, S. S., and Murugan, K.: Taxonomic discrimination of Solanum nigrum and S. giganteum by Fourier transform infrared spectroscopy Data, J. Res. Biol., 2, 482-488, 2012.

Augustin, S., Wex, H., Niedermeier, D., Pummer, B., Grothe, H., Hartmann, S., Tomsche, L., Clauss, T., Voigtländer, J., Ignatius, K., and Stratmann, F.: Immersion freezing of birch pollen washing water, Atmos. Chem. Phys., 13, 10989-11003, https://doi.org/10.5194/acp-13-10989-2013, 2013.

Bağcioğu, M., Zimmermann, B., and Kohler, A.: A multiscale vibrational spectroscopic approach for identification and biochemical characterization of pollen, PLoS One, 10, 1-19, https://doi.org/10.1371/journal.pone.0137899, 2015.

Baker, M. B.: Cloud microphysics and climate, Science, 276, 10721078, https://doi.org/10.1126/science.276.5315.1072, 1997.

Baker, M. J., Trevisan, J., Bassan, P., Bhargava, R., and Butler, H. J.: Using Fourier transform IR spectroscopy to analyze biological materials, Nat. Protoc., 9, 1771-1791, https://doi.org/10.1038/nprot.2014.110.Using, 2015.

Beck, P., Caudullo, G., de Rigo, D., and Tinner, W.: Betula pendula, Betula pubescens and other birches in Europe: distribution, habitat, usage and threats, edited by: San-Miguel-Ayanz, J., de Rigo, D., Caudullo, G., Houston Durrant, T., and Mauri, A., Eur. Atlas For. Tree Species, Publ. Off. EU, Luxembourg, e010226+, 2016. 
Brush, R. A., Griffith, M., and Mlynarz, A.: Characterization and Quantification of Intrinsic Ice Nucleators in Winter Rye (Secale-Cereale) Leaves, Plant Physiol., 104, 725-735, https://doi.org/10.1104/pp.104.2.725, 1994.

Burke, M. J., Gusta, L. V., Quamme, H. A., Weiser, C. J., and Li, P. H.: Freezing and Injury in Plants, Annu. Rev. Plant Physiol., 27, 507-528, https://doi.org/10.1146/annurev.pp.27.060176.002451, 1976.

Cantrell, W. and Heymsfield, A.: Production of ice in tropospheric clouds: A review, B. Am. Metreorol. Soc., 86, 795-807, https://doi.org/10.1175/BAMS-86-6-795, 2005.

Carballo-Meilan, A., Goodman, A. M., Baron, M. G., and Gonzalez-Rodriguez, J.: A specific case in the classification of woods by FTIR and chemometric: Discrimination of Fagales from Malpighiales, Cellulose, 21, 261-273, https://doi.org/10.1007/s10570-013-0093-2, 2014.

Chen, H., Ferrari, C., Angiuli, M., Yao, J., Raspi, C., and Bramanti, E.: Qualitative and quantitative analysis of wood samples by Fourier transform infrared spectroscopy and multivariate analysis, Carbohydr. Polym., 82, 772-778, https://doi.org/10.1016/j.carbpol.2010.05.052, 2010.

Christner, B. C., Cai, R., Morris, C. E., McCarter, K. S., Foreman, C. M., Skidmore, M. L., Montross, S. N., and Sands, D. C.: Geographic, seasonal, and precipitation chemistry influence on the abundance and activity of biological ice nucleators in rain and snow, P. Natl. Acad. Sci. USA, 105, 18854-18859, https://doi.org/10.1073/pnas.0809816105, 2008.

Conen, F., Morris, C. E., Leifeld, J., Yakutin, M. V., and Alewell, C.: Biological residues define the ice nucleation properties of soil dust, Atmos. Chem. Phys., 11, 9643-9648, https://doi.org/10.5194/acp-11-9643-2011, 2011.

Conen, F., Stopelli, E., and Zimmermann, L.: Clues that decaying leaves enrich Arctic air with ice nucleating particles, Atmos. Environ., 129, 91-94, https://doi.org/10.1016/j.atmosenv.2016.01.027, 2016.

Conen, F., Yakutin, M. V, Yttri, K. E., and Hüglin, C.: Ice Nucleating Particle Concentrations Increase When Leaves Fall in Autumn, Atmosphere, 8, 1-9, https://doi.org/10.3390/atmos8100202, 2017.

DeMott, P. J.: An Exploratory Study of Ice $\mathrm{Nu}-$ cleation by Soot Aerosols, J. Appl. Meteorol., 29, 1072-1079, https://doi.org/10.1175/15200450(1990)029<1072:AESOIN>2.0.CO;2, 1990.

DeMott, P. J., Prenni, A. J., Liu, X., Kreidenweis, S. M., Petters, M. D., Twohy, C. H., Richardson, M. S., Eidhammer, T., and Rogers, D. C.: Predicting global atmospheric ice nuclei distributions and their impacts on climate, P. Natl. Acad. Sci. USA, 107, 1121711222, https://doi.org/10.1073/pnas.0910818107, 2010.

DePuy, V., Berger, V. W., and Zhou, Y.: Wilcoxon-Mann-Whitney Test, edited by: Everitt, P. S. and Howell, D. C., Encyclopedia of Statistics in Behavioral Science, 4, 2118-2121, 2005.

Diehl, K., Quick, C., Matthias-Maser, S., Mitra, S. K., and Jaenicke, R.: The ice nucleating ability of pollen Part I: Laboratory studies in deposition and condensation freezing modes, Atmos. Res., 58, 75-87, https://doi.org/10.1016/S0169-8095(01)00091-6, 2001.

Dorsey, N. E.: The Freezing of Supercooled Water, Trans. Am. Philos. Soc., 38, 247-328, https://doi.org/10.2307/1005602, 1948.

Dreischmeier, K., Budke, C., Wiehemeier, L., Kottke, T., and Koop, T.: Boreal pollen contain ice-nucleating as well as ice- binding "antifreeze" polysaccharides, Sci. Rep.-UK, 7, 41890, https://doi.org/10.1038/srep41890, 2017.

Eichelmann, H., Oja, V., Rasulov, B., Padu, E., Bichele, I., Pettai, H., Mänd, P., Kull, O., and Laisk, A.: Adjustement of leaf photosynthesis to chade in a natural canopy: reallocation of nitrogen, Plant. Cell Environ., 28, 389-401, https://doi.org/10.1111/j.1365-3040.2004.01275.x, 2005.

Felgitsch, L., Baloh, P., Burkart, J., Mayr, M., Momken, M. E., Seifried, T. M., Winkler, P., Schmale III, D. G., and Grothe, H.: raw data of the manuscript "Birch leaves and branches as a source of ice-nucleating macromolecules", Version 1.1, Data set, Zenodo, https://doi.org/10.5281/zenodo.1461817, 2018.

Forster, P., Ramaswamy, V., Artaxo, P., Berntsen, T., Betts, R., Fahey, D. W., Haywood, J., Lean, J., Lowe, D. C., Myhre, G., Nganga, J., Prinn, R., Raga, G., Schulz, M., and Van Dorland, R.: Changes in Atmospheric Constituents and in Radiative Forcing, in: Climate Change 2007: The Physical Science Basis, Contribution of Working Group I to the Fourth Assessment Report of the Intergovernmental Panel on Climate Change, edited by: Solomon, S., Qin, D., Manning, M., Chen, Z., Marquis, M., Averyt, K. B., Tignor, M., and Miller, H. L., Cambridge University Press, Cambridge, United Kingdom and New York, NY, USA, 2007.

Franco, V., Kousoulidou, M., Muntean, M., Ntziachristos, L., Hausberger, S., and Dilara, P.: Road vehicle emission factors development: A review, Atmos. Environ., 70, 84-97, https://doi.org/10.1016/j.atmosenv.2013.01.006, 2013.

Freer-Smith, P. H.: The influence of $\mathrm{SO}_{2}$ and $\mathrm{NO}_{2}$ on the growth, developement and gas exchange of Betula pendula roth, New Phytol., 99, 417-430, https://doi.org/10.1111/j.14698137.1985.tb03669.x, 1985.

Fröhlich-Nowoisky, J., Hill, T. C. J., Pummer, B. G., Yordanova, P., Franc, G. D., and Pöschl, U.: Ice nucleation activity in the widespread soil fungus Mortierella alpina, Biogeosciences, 12, 1057-1071, https://doi.org/10.5194/bg-12-1057-2015, 2015.

Gorgulu, S. T., Dogan, M., and Severcan, F.: The characterization and differentiation of higher plants by Fourier transform infrared spectroscopy, Appl. Spectrosc., 61, 300-308, https://doi.org/10.1366/000370207780220903, 2007.

Gottardini, E., Rossi, S., Cristofolini, F., and Benedetti, L.: Use of Fourier transform infrared (FT-IR) spectroscopy as a tool for pollen identification, Aerobiologia (Bologna), 23, 211-219, https://doi.org/10.1007/s10453-007-9065-z, 2007.

Govindarajan, A. G. and Lindow, S. E.: Size of bacterial ice-nucleation sites measured in situ by radiation inactivation analysis., P. Natl. Acad. Sci. USA, 85, 1334-1338, https://doi.org/10.1073/pnas.85.5.1334, 1988.

Harmens, H., Hayes, F., Sharps, K., Mills, G., and Calatayud, V.: Leaf traits and photosynthetic responses of Betula pendula saplings to a range of ground-level ozone concentrations at a range of nitrogen loads, J. Plant Physiol., 211, 42-52, https://doi.org/10.1016/j.jplph.2017.01.002, 2017.

Hauptmann, A., Handle, K. F., Baloh, P., Grothe, H., and Loerting, T.: Does the emulsification procedure influence freezing and thawing of aqueous droplets?, J. Chem. Phys., 145, 211923, https://doi.org/10.1063/1.4965434, 2016.

Hegg, D. A. and Baker, M. B.: Nucleation in the atmosphere, Rep. Prog. Phys., 72, 56801, https://doi.org/10.1088/00344885/72/5/056801, 2009. 
Hill, T. C. J., DeMott, P. J., Tobo, Y., Fröhlich-Nowoisky, J., Moffett, B. F., Franc, G. D., and Kreidenweis, S. M.: Sources of organic ice nucleating particles in soils, Atmos. Chem. Phys., 16, 7195-7211, https://doi.org/10.5194/acp-16-7195-2016, 2016.

Hiranuma, N., Möhler, O., Yamashita, K., Tajiri, T., Saito, A., Kiselev, A., Hoffmann, N., Hoose, C., Jantsch, E., Koop, T., and Murakami, M.: Ice nucleation by cellulose and its potential contribution to ice formation in clouds, Nat. Geosci., 8, 273-277, https://doi.org/10.1038/ngeo2374, 2015.

Hirsh, A. G., Williams, R. J., and Merymen, H. T.: A Novel Method of Natural Cryoprotection: Intracellular Glass Formation in Deeply Frozen Populus, Plant Physiol., 79, 41-56, https://doi.org/10.1104/pp.79.1.41, 1985.

Hoose, C. and Möhler, O.: Heterogeneous ice nucleation on atmospheric aerosols: a review of results from laboratory experiments, Atmos. Chem. Phys., 12, 9817-9854, https://doi.org/10.5194/acp-12-9817-2012, 2012.

Huffman, J. A., Prenni, A. J., DeMott, P. J., Pöhlker, C., Mason, R. H., Robinson, N. H., Fröhlich-Nowoisky, J., Tobo, Y., Després, V. R., Garcia, E., Gochis, D. J., Harris, E., MüllerGermann, I., Ruzene, C., Schmer, B., Sinha, B., Day, D. A., Andreae, M. O., Jimenez, J. L., Gallagher, M., Kreidenweis, S. M., Bertram, A. K., and Pöschl, U.: High concentrations of biological aerosol particles and ice nuclei during and after rain, Atmos. Chem. Phys., 13, 6151-6164, https://doi.org/10.5194/acp13-6151-2013, 2013.

Iannone, R., Chernoff, D. I., Pringle, A., Martin, S. T., and Bertram, A. K.: The ice nucleation ability of one of the most abundant types of fungal spores found in the atmosphere, Atmos. Chem. Phys., 11, 1191-1201, https://doi.org/10.5194/acp-111191-2011, 2011.

Jaenicke, R.: Abundance of cellular material and proteins in the atmosphere, Science, 308, 73 pp., https://doi.org/10.1126/science.1106335, 2005.

Jann, A., Lundheim, R., Niederberger, P., and Richard, M.: Increasing freezing point of food with sea buckthorn ice nucleating agent, US Patent No. 5665361, 1997.

Jia, Y., Bhat, S., and Fraser, M. P.: Characterization of saccharides and other organic compounds in fine particles and the use of saccharides to track primary biologically derived carbon sources, Atmos. Environ., 44, 724-732, https://doi.org/10.1016/j.atmosenv.2009.10.034, 2010.

Johansson, T: Biomass equations for determining fractions of pendula and pubescent birches growing on abandoned farmland and some practical implications, Biomass Bioenerg., 16, 223-238, https://doi.org/10.1016/S0961-9534(98)00075-0, 1999.

Kačuráková, M., Capek, P., Sasinkova, V., Wellner, N., Ebringerova, A., and Kac, M.: FTIR study of plant cell wall model compounds?: pectic polysaccharides and hemicelluloses, Carbohydrate Polymers, 43, 195-203, https://doi.org/10.1016/S01448617(00)00151-X, 2000.

Kamphus, M., Ettner-Mahl, M., Klimach, T., Drewnick, F., Keller, L., Cziczo, D. J., Mertes, S., Borrmann, S., and Curtius, J.: Chemical composition of ambient aerosol, ice residues and cloud droplet residues in mixed-phase clouds: single particle analysis during the Cloud and Aerosol Characterization Experiment (CLACE 6), Atmos. Chem. Phys., 10, 8077-8095, https://doi.org/10.5194/acp-10-8077-2010, 2010.
Kieft, T. L.: Ice nucleation activity in lichens., Appl. Environ. Microbiol., 54, 1678-1681, 1988.

Kim, S. W., Ban, S. H., Chung, H., Cho, S., Chung, H. J., Choi, P. S., Yoo, O. J., and Liu, J. R.: Taxonomic discrimination of flowering plants by multivariate analysis of Fourier transform infrared spectroscopy data, Plant Cell Rep., 23, 246-250, https://doi.org/10.1007/s00299-004-0811-1, 2004.

Kishimoto, T., Yamazaki, H., Saruwatari, A., Murakawa, H., Sekozawa, Y., Kuchitsu, K., Price, W. S., and Ishikawa, M.: High ice nucleation activity located in blueberry stem bark is linked to primary freeze initiation and adaptive freezing behaviour of the bark, AoB Plants, 6, 1-17, https://doi.org/10.1093/aobpla/plu044, 2014.

Kohn, M.: Laboratory and field measurements of immersion freezing utilizing a newly developed cloud chamber, ETH Zürich, https://doi.org/10.3929/ethz-a-010784171, 2016.

Kuokkanen, K., Julkunen-Tiitto, R., Keinänen, M., Niemelä, P., and Tahvanainen, J.: The effect of elevated $\mathrm{CO}_{2}$ and temperature on the secondary chemistry of Betula pendula seedlings, Trees, 15, 378-384, https://doi.org/10.1007/s004680100108, 2001.

Lohmann, U.: A glaciation indirect aerosol effect caused by soot aerosols, Geophys. Res. Lett., 29, 1052, https://doi.org/10.1029/2001g1014357, 2002.

Lundheim, R. and Wahlberg, K.: Ice nucleation in fruit juice from different varieties of sea buckthorn Hippophaë rhamnoides L., Euphytica, 102, 117-124, https://doi.org/10.1023/A:1018336413479, 1998.

Magel, E., Einig, W., and Hampp, R.: Carbohydrates in trees, Dev. Crop Sci., 26, 317-336, https://doi.org/10.1016/S0378519X(00)80016-1, 2000.

Maki, L. R., Galyan, E. L., Chang-Chien, M. M., and Caldwell, D. R.: Ice nucleation induced by pseudomonas syringae, Appl. Microbiol., 28, 456-459, https://doi.org/10.1111/1462-2920.12668, 1974.

Martin, B., Bytnerowicz, A., and Thorstenson, Y. R.: Effects of air pollutants on the composition of stable carbon isotopes, $\delta^{13} \mathrm{C}$, of leaves and wood, and on leaf injury, Plant Physiol., 88, 218-223, https://doi.org/10.1104/pp.88.1.218, 1988.

Matthias-Maser, S. and Jaenicke, R.: The size distribution of primary biological aerosol particles with radii $>0.2$ in an urban/rural influenced region, Atmos. Res., 39, 279-286, https://doi.org/10.1016/0169-8095(95)00017-8, 1995.

Maurer, S. and Matyssek, R.: Nutrition and the ozone sensitivity of birch (Betula pendula), Trees, 12, 1-10, https://doi.org/10.1007/s004680050116, 1997.

Mazur, P.: Freezing Injury in Plants, Annu. Rev. Plant Physiol., 20, 419-448, https://doi.org/10.1146/annurev.pp.20.060169.002223, 1969.

Mishchenko, M. I., Rossow, W. B., Macke, A., and Lacis, A. A.: Sensitivity of cirrus cloud albedo, bidirectional reflectance and optical thickness retrieval accuracy to ice particle shape, J. Geophys. Res., 101, 16973-16985, https://doi.org/10.1029/96JD01155, 1996.

Miyazawa, T., Shimanouchi, T., and Mizushima, S.: Characteristic Infrared Bands of Monosubstituted Amides, J. Chem. Phys., 24, 408-418, https://doi.org/10.1063/1.1742489, 1956.

Möhler, O., DeMott, P. J., Vali, G., and Levin, Z.: Microbiology and atmospheric processes: the role of biological 
particles in cloud physics, Biogeosciences, 4, 1059-1071, https://doi.org/10.5194/bg-4-1059-2007, 2007.

Monier, J.-M. and Lindow, S. E.: Pseudomonas syringae Responds to the Environment on Leaves by Cell Size Reduction, Phytopathology, 93, 1209-1216, https://doi.org/10.1094/PHYTO.2003.93.10.1209, 2003.

Morris, C. E., Conen, F., Alex Huffman, J., Phillips, V., Pöschl, U., and Sands, D. C.: Bioprecipitation: A feedback cycle linking Earth history, ecosystem dynamics and land use through biological ice nucleators in the atmosphere, Global Chang. Biol., 20, 341-351, https://doi.org/10.1111/gcb.12447, 2014.

Murray, B. J., Broadley, S. L., Wilson, T. W., Bull, S. J., Wills, R. H., Christenson, H. K., and Murray, E. J.: Kinetics of the homogeneous freezing of water, Phys. Chem. Chem. Phys., 12 1038010387, https://doi.org/10.1039/c003297b, 2010.

Murray, B. J., O'Sullivan, D., Atkinson, J. D., and Webb, M. E.: Ice nucleation by particles immersed in supercooled cloud droplets, Chem. Soc. Rev., 41, 6519-6554, https://doi.org/10.1039/c2cs35200a, 2012.

O’Sullivan, D., Murray, B. J., Malkin, T. L., Whale, T. F., Umo, N. S., Atkinson, J. D., Price, H. C., Baustian, K. J., Browse, J., and Webb, M. E.: Ice nucleation by fertile soil dusts: relative importance of mineral and biogenic components, Atmos. Chem. Phys., 14, 1853-1867, https://doi.org/10.5194/acp-141853-2014, 2014.

O’Sullivan, D., Murray, B. J., Ross, J. F., Whale, T. F., Price, H. C., Atkinson, J. D., Umo, N. S., and Webb, M. E.: The relevance of nanoscale biological fragments for ice nucleation in clouds, Sci. Rep.-UK, 5, 8082, https://doi.org/10.1038/srep08082, 2015.

O'Sullivan, D., Murray, B. J., Ross, J. F., and Webb, M. E.: The adsorption of fungal ice-nucleating proteins on mineral dusts: a terrestrial reservoir of atmospheric ice-nucleating particles, Atmos. Chem. Phys., 16, 7879-7887, https://doi.org/10.5194/acp16-7879-2016, 2016.

Pearce, R.: Plant Freezing and Damage, Ann. Bot., 87, 417-424, https://doi.org/10.1006/anbo.2000.1352, 2001.

Petters, M. D. and Wright, T. P.: Revisiting ice nucleation from precipitation samples, Geophys. Res. Lett., 42, 8758-8766, https://doi.org/10.1002/2015GL065733, 2015.

Pouleur, S., Richard, C., Martin, J., and Antoun, H.: Ice Nucleation Activity in Fusarium acuminatum and Fusarium avenaceumt, 58, 2960-2964, 1992.

Pratt, K. A., DeMott, P. J., French, J. R., Wang, Z., Westphal, D. L., Heymsfield, A. J., Twohy, C. H., Prenni, A. J., and Prather, K. A.: In situ detection of biological particles in cloud ice-crystals, Nat. Geosci., 2, 398-401, https://doi.org/10.1038/ngeo521, 2009.

Pruppbacher, H. R. and Klett, J. D.: Microphysics of Clouds and Precipitation, 2nd edn., Kluwer Acedemic Publishers, Dordrecht, ISBN:0-7923-4211-9, 1997.

Pummer, B. G., Bauer, H., Bernardi, J., Bleicher, S., and Grothe, H.: Suspendable macromolecules are responsible for ice nucleation activity of birch and conifer pollen, Atmos. Chem. Phys., 12, 2541-2550, https://doi.org/10.5194/acp-12-2541-2012, 2012.

Pummer, B. G., Bauer, H., Bernardi, J., Chazallon, B., Facq, S., Lendl, B., Whitmore, K., and Grothe, H.: Chemistry and morphology of dried-up pollen suspension residues, J. Raman Spectrosc., 44, 1654-1658, https://doi.org/10.1002/jrs.4395, 2013.

Pummer, B. G., Budke, C., Augustin-Bauditz, S., Niedermeier, D., Felgitsch, L., Kampf, C. J., Huber, R. G., Liedl, K.
R., Loerting, T., Moschen, T., Schauperl, M., Tollinger, M., Morris, C. E., Wex, H., Grothe, H., Pöschl, U., Koop, T., and Fröhlich-Nowoisky, J.: Ice nucleation by watersoluble macromolecules, Atmos. Chem. Phys., 15, 4077-4091, https://doi.org/10.5194/acp-15-4077-2015, 2015.

Rey, A. and Jarvis, P. G.: Long-term photosynthetic acclimation to increased atmospheric $\mathrm{CO}_{2}$ concentration in young birch (Betula pendula) tree, Tree Physiol., 18, 441-450, https://doi.org/10.1093/treephys/18.7.441, 1998.

Rogers, D. C., DeMott, P. J., Kreidenweis, S. M., and Chen, Y.: Measurements of ice nucleating aerosols during SUCCESS, Geophys. Res. Lett., 25, 1383-1386, https://doi.org/10.1029/97GL03478, 1998.

Sakai, A.: Characteristics of winter hardiness in extremely hardy twigs of woody plants, Plant Cell Physiol., 14, 1-9, https://doi.org/10.1093/oxfordjournals.pcp.a074830, 1973.

Sánchez-Ochoa, A., Kasper-Giebl, A., Puxbaum, H., Gelencser, A., Legrand, M., and Pio, C. A.: Concentration of atmospheric cellulose: A proxy for plant debris across a westeast transect over Europe, J. Geophys. Res.-Atmos., 112, 1-8, https://doi.org/10.1029/2006JD008180, 2007.

Sands, D. C., Langham, V. E., Scharen, A. L., and de Smet, C.: The association between bacteria and rain and possible resultant meteorological implications, Időjárás, 86, 148-152, 1982.

Schnell, R. C. and Vali, G.: World-wide Source of Leaf-derived Freezing Nuclei, Nature, 246, 212-213, https://doi.org/10.1038/246212a0, 1973.

Schulz, H. and Baranska, M.: Identification and quantification of valuable plant substances by IR and Raman spectroscopy, Vib. Spectrosc., 43, 13-25, https://doi.org/10.1016/j.vibspec.2006.06.001, 2007.

Sellin, A. and Kupper, P.: Effects of enhanced hydraulic supply for foliage on stomatal responses in little-leaf linden (Tilia cordata Mill.), Eur. J. For. Res., 126, 241-251, https://doi.org/10.1007/s10342-006-0140-8, 2007.

Sellin, A., Sack, L., Õunapuu, E., and Karusion, A.: Impact of light quality on leaf and shoot hydraulic properties: A case study in silver birch (Betula pendula), Plant, Cell Environ., 34, 1079-1087, https://doi.org/10.1111/j.1365-3040.2011.02306.x, 2011.

Sellin, A., Tullus, A., Niglas, A., Õunapuu, E., Karusion, A., and Lõhmus, K.: Humidity-driven changes in growth rate, photosynthetic capacity, hydraulic properties and other functional traits in silver birch (Betula pendula), Ecol. Res., 28, 523-535, https://doi.org/10.1007/s11284-013-1041-1, 2013.

Sperry, J. S. and Sullivan, J. E. M.: Xylem Embolism in Response to Freeze-Thaw Cycles and Water Stress in Ring-Porous, Diffuse-Porous, and Conifer Species, Plant Physiol., 100, 605613, https://doi.org/10.1104/pp.100.2.605, 1992.

Spracklen, D. V., Carslaw, K. S., Merikanto, J., Mann, G. W., Reddington, C. L., Pickering, S., Ogren, J. A., Andrews, E., Baltensperger, U., Weingartner, E., Boy, M., Kulmala, M., Laakso, L., Lihavainen, H., Kivekäs, N., Komppula, M., Mihalopoulos, N., Kouvarakis, G., Jennings, S. G., O’Dowd, C., Birmili, W., Wiedensohler, A., Weller, R., Gras, J., Laj, P., Sellegri, K., Bonn, B., Krejci, R., Laaksonen, A., Hamed, A., Minikin, A., Harrison, R. M., Talbot, R., and Sun, J.: Explaining global surface aerosol number concentrations in terms of primary emissions and particle formation, Atmos. Chem. Phys., 10, 4775-4793, https://doi.org/10.5194/acp-10-4775-2010, 2010. 
Storey, J. M. and Storey, K. B.: Cold Hardiness and Freeze Tolerance, in: Functional Metabolism: Regulation and Adaptation, edited by: Storey, K. B., John Wiley \& Sons Inc, Hoboken, 470503, https://doi.org/10.1002/047167558X.ch17, 2004.

Tobo, Y., DeMott, P. J., Hill, T. C. J., Prenni, A. J., SwobodaColberg, N. G., Franc, G. D., and Kreidenweis, S. M.: Organic matter matters for ice nuclei of agricultural soil origin, Atmos. Chem. Phys., 14, 8521-8531, https://doi.org/10.5194/acp14-8521-2014, 2014.

Tong, H.-J., Ouyang, B., Nikolovski, N., Lienhard, D. M., Pope, F. D., and Kalberer, M.: A new electrodynamic balance (EDB) design for low-temperature studies: application to immersion freezing of pollen extract bioaerosols, Atmos. Meas. Tech., 8, 11831195, https://doi.org/10.5194/amt-8-1183-2015, 2015.

Truong, C., Palmé, A. E., and Felber, F.: Recent invasion of the mountain birch Betula pubescens ssp. tortuosa above the treeline due to climate change: Genetic and ecological study in northern Sweden, J. Evol. Biol., 20, 369-380, https://doi.org/10.1111/j.1420-9101.2006.01190.x, 2007.

Turnball, D. and Fisher, J. C.: Rate of Nucleation in Condensed Systems, J. Chem. Phys., 17, 71-73, https://doi.org/10.1063/1.1747055, 1949.

Uri, V., Löhmus, K., Ostonen, I., Tullus, H., Lastik, R., and Vildo, M.: Biomass production, foliar and root characteristics and nutrient accumulation in young silver birch (Betula pendula Roth.) stand growing on abandoned agricultural land, Eur. J. For. Res., 126, 495-506, https://doi.org/10.1007/s10342-007-0171-9, 2007.
Vali, G.: Quantitative Evaluation of Experimental Results an the Heterogeneous Freezing Nucleation of Supercooled Liquids, J. Atmos. Sci., 28, 402-409, https://doi.org/10.1175/15200469(1971)028<0402:QEOERA>2.0.CO;2.37, 1971

Vali, G., DeMott, P. J., Möhler, O., and Whale, T. F.: Technical Note: A proposal for ice nucleation terminology, Atmos. Chem. Phys., 15, 10263-10270, https://doi.org/10.5194/acp-15-102632015, 2015.

Winiwarter, W., Bauer, H., Caseiro, A., and Puxbaum, H.: Quantifying emissions of primary biological aerosol particle mass in Europe, Atmos. Environ., 43, 1403-1409, https://doi.org/10.1016/j.atmosenv.2008.01.037, 2009.

Zachariassen, K. E. and Kristiansen, E.: Ice Nucleation and Antinucleation in Nature, Cryobiology, 41, 257-279, https://doi.org/10.1006/cryo.2000.2289, 2000.

Zimmermann, B. and Kohler, A.: Infrared spectroscopy of pollen identifies plant species and genus as well as environmental conditions, PLoS One, 9, e95417, https://doi.org/10.1371/journal.pone.0095417, 2014. 